\title{
The Corporation, New Governance, and the Power of the Publicization Narrative
}

\author{
Fenner Stewart \\ University of Calgary, fenner.stewart@ucalgary.ca
}

Follow this and additional works at: https://www.repository.law.indiana.edu/ijgls

Part of the Business Organizations Law Commons, and the International Law Commons

\section{Recommended Citation}

Stewart, Fenner (2014) "The Corporation, New Governance, and the Power of the Publicization Narrative," Indiana Journal of Global Legal Studies: Vol. 21 : Iss. 2 , Article 5.

Available at: https://www.repository.law.indiana.edu/ijgls/vol21/iss2/5

This Article is brought to you for free and open access by the Law School Journals at Digital Repository @ Maurer Law. It has been accepted for inclusion in Indiana Journal of Global Legal Studies by an authorized editor of Digital Repository @ Maurer Law. For more information, please contactrvaughan@indiana.edu.

\section{$\Psi$}

JEROME HALL LAW LIBRARY

INDIANA UNIVERSITY

Maurer School of Law
Blooming ton 


\title{
The Corporation, New Governance, and the Power of the Publicization Narrative
}

\author{
FENNER L. STEWART ${ }^{*}$
}

\begin{abstract}
"The Corporation, New Governance, and the Power of the Publicization Narrative" takes a critical look at the idea of publicization and how it plays out within new governance. Publicization is a vague, but powerful, notion that the delegation of public power to for-profit agents-what John Braithwaite calls the "privatization of the public"will lead to such agents exercising this power as idealized public servants-what Braithwaite calls the "publicization of the private." This article argues that publicization of the private is a dangerous metaphor, which offers a romanticized picture of functionally efficient, decentered actors acting with the integrity of public servants. This article suggests that "publicization of the private" is an empty promise that will lead the faithful to be less critical of privatization. Accordingly, this article suggests that new governance initiatives may be leading to the privatization of the public without the publicization of the private.
\end{abstract}

\section{INTRODUCTION}

In Regulatory Capitalism: How it Works, Ideas for Making it Work Better, John Braithwaite wrote an eye-catching phrase: regulatory capitalism represents the "reality of hybridity between the privatization of the public and publicization of the private." 1 The privatization of the

* Fenner Stewart is an Assistant Professor of Law at the University of Calgary Faculty of Law. He is a member of the University of Calgary's Energy Research Strategy, entitled "Energy Innovation for Today and Tomorrow." This confederation of scholars is a new inter-faculty cluster from the Faculty of Arts, the Schulich School of Engineering, the Haskayne School of Business, and the Faculty of Law. The scholastic assembly's goal is to help the University become a world leader in energy research. Professor Stewart is also a Director of the Midwest Center for Energy Law and Policy.

1. John BRaithWaite, REgUlatory CAPITALISM: How IT WORKS, IDEAS FOR MAKING IT WORK BETTER 8 (2008).

Indiana Journal of Global Legal Studies Vol. 21 \#2 (Summer 2014)

(C) Indiana University Maurer School of Law 
public had been well documented, ${ }^{2}$ but the idea of publicization of the private appeared to hold new promise. ${ }^{3}$ I had spotted Braithwaite's new optimism earlier in a 2006 working paper, when he admitted that he had been concerned about the neoliberal shift toward privatization, ${ }^{4}$ even though he had been endorsing the self-governance of private actors for some time. ${ }^{5}$ But now (as of 2006), he was convinced that his fears regarding neoliberalism were excessive, and that it was merely a stage of "regulatory capitalism." 6

In April of 2013, Braithwaite released a new working paper that further extrapolates on publicization, explaining that it means "the percolation of public law values into private law and into corporate selfregulation [, including] the most critical public law values such as transparency, accountability, stakeholder voice and separations of powers." Jody Freeman, the originator of this idea, described publicization as a process by which "private actors increasingly commit themselves to traditionally public goals as the price of access to lucrative opportunities . . . that might otherwise be provided directly by the state."8

However, in the decade since Freeman hypothesized that this publicization would occur, there has been little evidence of such a transformation. ${ }^{9}$ For better or worse, business actors do not appear to be any more or less imbued with the spirit of public service than in the past, leaving questions as to whether recent regulatory experimentation

2. See, e.g., Daniel Yergin \& Joseph Stanislaw, The Commanding Heights: The BATTLE FOR THE WORLD ECONOMY (rev. ed. 2002).

3. For the origins of the concept, see Jody Freeman, Extending Public Law Norms Through Privatization, 116 HARV. L. REv. 1285, 1285 (2003).

4. See generally John Braithwaite, Neoliberalism or Regulatory Capitalism (Austl. Nat'l Univ. Regulatory Insts. Network, Occasional Paper No. 5, 2005), available at https://www.anu.edu.au/fellows/jbraithwaite/_documents/Articles/Neoliberalism_Regulato ry_2005.pdf.

5. See generally IAN AYRES \& JOHN BRAITHWAITE, RESPONSIVE REgUlation: TRANSCENDING THE DEREgUlation DEBATE (1992).

6. Braithwaite, supra note 4 , at 8,18 . Regulatory Capitalism is a theory that suggests the global political economy is evermore reliant on administrative rules even though such rules many not emanate from traditional sources like national legislatures and courts. It rejects the central argument of deregulation that there is a decline in regulation, providing much empirical evidence to the fact that there is a profound expansion of regulation. See generally David Levi-Faur \& Jacint Jordana, The Rise of Regulatory Capitalism: The Global Diffusion of a New Order, 598 ANNALS AM. ACAD. POL. \& SoC. SCI. 6 (2005).

7. John Braithwaite, Strategic Socialism, Strategic Privatization and Crisis 4 (Austl. Nat'l Univ. Regulatory Insts. Network, Working Paper No. 2013/11, 2013), available at http://papers.ssrn.com/sol3/papers.cfm?abstract_id=2249544.

8. Freeman, supra note 3, at 1285.

9. See, e.g., Braithwaite, supra note 7 , at 5 . 
has come at the expense of the long-term integrity of governance. ${ }^{10}$ Both the collapse of Enron and the credit crisis have been, in large part, attributable to the regulatory failures caused by the decisions of forprofit "gatekeepers,"11 such as Arthur Andersen ${ }^{12}$ and Standard \& Poor's.13 These "gatekeepers" were enjoying the sort of lucrative opportunities that Freeman had envisioned but failed to adequately publicize as she predicted.

In light of the continued interest in the idea of publicization, this article offers some considerations that might be taken into account when attempting to evaluate its potential. To do so, this article, in part, takes a second look at the literatures supporting "new governance" initiatives that expose the publicization of the private. New governance is an umbrella term for theories of governance that encourage regulatory architects to marry the best of both the public and private orderings. ${ }^{14}$ It celebrates a "blurring" of public and private functions within areas of regulation. ${ }^{15}$

10. See generally Peer Zumbansen, Transnational Private Regulatory Governance: Ambiguities of Public Authority and Private Power (Osgoode Hall Law Sch. Comp. Res. in Law \& Pol. Econ., Working Paper No. 22/2013, 2013), available at http://ssrn.com/abstract=2252208.

11. John C. COFfee JR., GatekeEpers: The Professions and CoRporate GOVERNANCE 1-6 (2006).

12. See, e.g., Kristen Hays, Enron at Eye Level: A Reporter's View of the Trials, in ENRon and OTHER Corporate Fiascos: The CoRporate SCANDAl READER 3 (Nancy B. Rapoport et al. eds., 2d ed. 2009); Theodore Eisenberg \& Jonathan R. Macey, Was Arthur Andersen Different? An Empirical Examination of Major Accounting Firm Audits of Large Clients, 1 J. EMPIRICAL LEGAL STUD. 263 (2004) (concluding that after controlling for client size, region, time, and industry, there was no evidence that Andersen's performance significantly differed from other large accounting firms).

13. See John C. Coffee Jr., What Went Wrong? An Initial Inquiry into the Causes of the 2008 Financial Crisis, 9 J. CORP. L. STUD. 1, 10-13 (2009), for how investment banks exploit new governance regulations to more than double the maximum leverage (15:1) allowable under regulatory requirements. Frank Partnoy argues that credit rating agencies have "little incentive to 'get it right," which "pose[s] a systemic risk." Frank Partnoy, Rethinking Regulation of Credit Rating Agencies: An Institutional Investor Perspective 3 (Univ. of San Diego Sch. of Law, Legal Stud. Res. Paper Series, Working Paper No. 09-014, 2009), available at http://ssrn.com/abstract=1430608. Timothy Sinclair identifies that the issue is conventionally conceived as that the way that credit rating agencies are remunerated generates a conflict of interest. He suggests that this conflict of interest is overblown and that focus should be on the challenges rating agencies (and similar gatekeepers) face, more generally, in a market system. See Timothy J. Sinclair, Credit Rating Agencies and the Global Financial Crisis, ECON. SoC., Nov, 2010, at 4,4 .

14. See generally Lisa T. Alexander, Reflections on Success and Failure in New Governance and the Role of the Lawyer, 2010 WIS. L. REV. 737; William H. Simon, New Governance Anxieties: A Deweyan Response, 2010 WIS. L. REV. 727; David Trubek \& 
The publicization dimension of new governance rhetoric invokes an out of focus image of the democratic delegation of power to for-profit agents, who, it is assumed, will exercise this power in a benevolent and efficient manner. For many regulatory scholars, with market failure to their left and regulatory failure to their right, publicization of the private represents a best-case metaphor whereby governance enjoys the optimal balance between the functional efficiencies of decentered actors ${ }^{16}$ and the integrity of idealized public servants. But again, this vision of publicization is out of focus and lacking in detail. This may be a serious problem if it creates a false promise of a panacea for the social ills attributed to privatization-such as the "democratic deficit" it creates. ${ }^{17}$

This article invites scholars to reconsider whether such blurring of public and private functions should be encouraged, and argues that the publicization of for-profit activities is a goal that is unlikely to be achieved. In light of Freeman's "ideal" of publicization, this article suggests that the best-case scenario for new governance may be merely the privatization of the public without the publicization of the private. And if this is the case then new governance, and its call for a further blurring of public and private functions, merits a critical re-evaluation.

Part I of this article provides an introduction to some of the literatures that inform new governance. Part II explores the normative strength of corporate governance to resist publicization. Part III looks at the challenges that technocratic narratives pose to publicization within both public and private governance. This article concludes by suggesting that, based on the arguments presented, for-profit actors will not publicize as the literature suggests. This conclusion invites further discussion as to the possibility of a more directed process that engineers a reconstitution of the public and private in light of the challenges facing modern governance, rather than just leaving it to the fortunes of market-driven "spontaneous evolution."

Louise Trubek, The World Turned Upside Down: Reflections on New Governance and the Transformation of Law, 2010 WIS. L. REV. 719.

15. See generally Jason M. Solomon, New Governance, Preemptive Self-Regulation, and the Blurring of Boundaries in Regulatory Theory and Practice, 2010 WIS. L. REV. 591.

16. See, e.g., Julia Black, Critical Reflections on Regulation, 27 AUSTL. J. LEGAL PHIL. 1 (2002). See also F. A. Hayek, The Use of Knowledge in Society, 35 AM. ECON. REV. 519 (1945).

17. See Alfred C. Aman, Jr., Law, Markets and Democracy: A Role for Law in the NeoLiberal State, 51 N.Y.L. SCH. L. REV. 801, 810-11 (2007). Of course, the concerns over the "democratic deficit" exist beyond privatization issues and are considered by those who are concerned about the entire project of new governance. See, e.g., GOVERNANCE AND THE DEMOCRATIC DEFICIT 307-11 (Victor Bekkers et al. eds., 2007). 


\section{THE FOUNDATION FOR NEW GOVERNANCE}

It is yet to be determined how new governance ${ }^{18}$ will play out. ${ }^{19}$ Thus, its merits are difficult to assess. The literature-if it is a single literature-is fragmented: collaborative, ${ }^{20}$ incentive-based, ${ }^{21}$ reflexive, ${ }^{22}$ responsive, ${ }^{23}$ and decentered ${ }^{24}$ notions of governance are not necessarily mindful of each other and appear not to be moving toward a single cohesive position. Attempts to synthesize the new governance

18. See Orly Lobel, New Governance as Regulatory Governance, in THE OXFoRD HANDBOOK OF GOVERNANCE 65, 65 (David Levi-Faur ed., 2012), for a definition of new governance. "[N]ew governance has emerged as a school of thought that focuses on the significance of institutional design and culture for effective and legitimate regulation. The development of new governance theory marks a paradigm shift from the old regulation by command and control to a regulatory governance model, signifying a collective intellectual and programmatic project for a new legal regime. New governance offers a vision of law and policy that draws on the comparative strengths of both private and public stakeholders and highlights the multiple ways in which the various actors in a society contribute to the acts of ordering social fields. New governance scholars begin with an analysis of both markets and governance failures to challenge the conventional wisdom that regulation must involve top-down command-and-control rules. Instead they attempt to offer a third-way vision between unregulated markets and top-down government controls."

19. For a reflection on the present transformation, see, for example, Lisa Blomgren Bingham, The Next Generation of Administrative Law: Building the Legal Infrastructure for Collaborative Governance, 2010 WIS. L. REV. 297; Mark Dawson, Transforming into What? New Governance in the EU and the "Managerial Sensibility" in Modern Law, 2010 WIS. L. REv. 389; Poul F. Kjaer, The Metamorphosis of the Functional Synthesis: $A$ Continental European Perspective on Governance, Law, and the Political in the Transnational Space, 2010 WIS. L. REV. 489; Trubek \& Trubek, supra note 14.

20. See, e.g., Jody Freeman, Collaborative Governance in the Administrative State, 45 UCLA L. REV. 1 (1997); Philip J. Harter, Collaboration: The Future of Governance, $2009 \mathrm{~J}$. DISP. RESOL. 411 (2009).

21. See, e.g., Lily N. Chinn, Can the Market Be Fair and Efficient? An Environmental Justice Critique of Emissions Trading, 26 ECOLOGY L.Q. 80, 80-88, 102-25 (1999); Daniel H. Cole \& Peter Z. Grossman, When is Command-and-Control Efficient? Institutions, Technology, and the Comparative Efficiency of Alternative Regulatory Regimes for Environmental Protection, 1999 WIS. L. REV. 887, 887-94, 935-38; Richard B. Stewart, $A$ New Generation of Environmental Regulation?, 29 CAP. U. L. REV. 21, 94-127 (2001).

22. See, e.g., UlRICH BECK, RISIKOGESELLSCHAFT: AUF DEM WEG IN EINE ANDERE MODERNE (1986) (Ger.), translated in RISK SOCIETY: TOWARDS A NEW MODERNITY (1992); Ulrich Beck et al., The Theory of Reflexive Modernization: Problematic, Hypotheses and Research Programme, 20 THEORY CulTURE \& SOC'Y 1 (2003); Peer Zumbansen, Law After the Welfare State: Formalism, Functionalism, and the Ironic Turn of Reflexive Law, 56 AM. J. CoMP. L. 769 (2008).

23. See, e.g., AYRES \& BRAITHWAITE, supra note 5; BRAITHWAITE, supra note 1; David Levi-Faur, The Global Diffusion of Regulatory Capitalism, 598 ANNALS AM. ACAD. POL. \& Soc. SCI. 12 (2005).

24. See, e.g., Julia Black, Decentring Regulation: Understanding the Role of Regulation and Self-Regulation in a 'Post-Regulatory' World, 54 CURRENT LEGAL ProBs. 103 (2001). 
literature ${ }^{25}$ have been charged with being "overzealous" 26 because these attempts invite a level of generalization that threatens to ignore important differences between the literatures. In this way, new governance is like critical legal theory ${ }^{27}$-and legal realism for that matter 28 -in the sense that, although a number of authors can be identified as being under the conceptual umbrella, the nature of the movement as a whole defies an all-inclusive definition. ${ }^{29}$

That being said, it is safe to assert that new governance is the study of the ways in which governments release their authority to regulate, or to enforce regulation, within regulated spaces, ${ }^{30}$ allowing nongovernment organizations to share in providing administrative functions traditionally associated with government. ${ }^{31}$ New governance may have replaced the command-and-control model of the welfare state. If so, it may replace the welfare state as the ideological ${ }^{32}$ binary pole to a pure free market, ${ }^{33}$ within the spectrum of "models of capitalism." ${ }^{34}$

25. See, e.g., Orly Lobel, The Renew Deal: The Fall of Regulation and the Rise of Governance in Contemporary Legal Thought, 89 MINN. L. REv. 342 (2004).

26. Bradley C. Karkkainen, "New Governance" in Legal Thought and in the World: Some Splitting as Antidote to Overzealous Lumping, 89 MINN. L. REV. 471 (2004).

27. For a discussion of the nature of the movement and its fragmentation, see generally Mark Tushnet, Critical Legal Studies: An Introduction to its Origins and Underpinnings, 36 J. LEGAL EDUC. 505 (1986).

28. Joseph Singer discusses the competing notion of legal realism and the idea that "[w]e are all legal realists now." Joseph William Singer, Legal Realism Now, 76 CALIF. L. REV. 465, 467 (1988) (book review).

29. See, e.g., id.; Tushnet, supra note 27.

30. A prime example of this is regulatory capitalism. See generally BRAITHWAITE, supra note 1. Although this does not bring additional clarity to the distinction between the sphere of new commerce and the locus of new governance, it is significant to note the distinctions that Braithwaite makes between understandings of neoliberalism, privatization, and regulatory capitalism. See Braithwaite, supra note 4.

31. See Colin Scott, Private Regulation of the Public Sector: A Neglected Facet of Contemporary Governance, 29 J.L. \& SoC'Y 56, 57-60 (2002).

32. Cukierman emphasizes the importance of ideology, among other forms of rationality, for its influence on economic policies, and thus the impact that ideology, for better or worse, has on macroeconomic developments. See Alex Cukierman, The Roles of Ideology, Institutions, Politics, and Economic Knowledge in Forecasting Macroeconomic Developments: Lessons from the Crisis, 56 CESIFo ECON. STUD. 575, 575-79 (2010). Thus, to reject ideology, when your opponents use it effectively as a tool for policy, is a disadvantage, pragmatically speaking, if the end goal is to influence policy development.

33. Yergin and Stanislaw tell a story of the ideological tension of the 20th Century as being between F.A. Hayek's free market ideology and J.M. Keynes's central planning. See generally YERGIN \& STANISLAW, supra note 2. See also Kari Polanyi-Levitt \& Marguerite Mendell, Karl Polanyi: His Life and Times, 22 STUD. POL. ECON. 7, 11 (1987).

34. See generally Colin Crouch, Models of Capitalism, 10 NEW POL. ECON. 439 (2005) (outlining the boundaries of models of capitalism). See also Richard Deeg \& Gregory Jackson, Towards a More Dynamic Theory of Capitalist Variety, 5 Socio-Econ. REv. 149 (2007) (arguing for more dynamism in comparative capitalisms literature). 
Accordingly, new governance may become the newest champion of "embedded liberalism."35

New governance literature today appears hopeful of the "reassertion of the public interest" within governance. ${ }^{36}$ Instead of framing the issue just ${ }^{37}$ within the context of the "turn to the market," 38 the "withdrawal of the welfare state," 39 or the "welfare state retrenchment," 40 new governance provides a place to imagine the reconstituting, ${ }^{41}$ restructuring, ${ }^{42}$ reasserting, ${ }^{43}$ or the rise ${ }^{44}$ of the public dimension of governance function. This appears to be the essential promise of new governance: to provide an alternative that is not antibusiness, ${ }^{45}$ yet still attempt to balance the demands of markets with the interests of society in a way that generates both sustainable and balanced policy options and a governance mechanism that stabilizes wealth creation, protects human dignity, and ensures a habitable natural environment for future

35. See John Gerard Ruggie, International Regimes, Transactions, and Change: Embedded Liberalism in the Postwar Economic Order, 36 INT'L ORG. 379, 392 (1982), coining the term "embedded liberalism." However, Ruggie was inspired to coin the term because of Karl Polanyi's work on "embedded" and "disembedded" economic orders. See Karl Polanyi, The Great Transformation: The Political and Economic Origins of OUR TIME, at xxii-xxv (2d ed. 2001).

36. See, e.g., David Levi-Faur, Regulatory Capitalism and the Reassertion of the Public Interest, 27 POL'Y \& SOC'Y 181 (2009).

37. Of course, this is not to take away from the important "turn to the market," "withdrawal of the welfare state," or "welfare state retrenchment" debates. It is only to say that different debates ought to also continue to emerge. Furthermore, the distinction drawn here is a precarious one in the sense that many of the authors of the privatization literature will also have a voice in these other literatures. Braithwaite, in particular, is drawing a similar distinction when he distinguishes between neoliberalism and regulatory capitalism. See generally Braithwaite, supra note 4. But such distinctions are not embraced by many and are to some degree artificial. However, it has been drawn presently in order to see what follows.

38. Bob Jessop, Governance Failure, in THE NEW POLITICs OF BRITISH LocaL, GovernaNCE 11, 11 (Gerry Stoker ed., 2000).

39. Vito Tanzi, Government Versus Markets: The Changing Economic Role of THE STATE 273 (2011).

40. See, e.g., Nathalie Giger \& Moira Nelson, The Electoral Consequences of Welfare State Retrenchment: Blame Avoidance or Credit Claiming in the Era of Permanent Austerity?, 50 EUR. J. POL. RES. 1 (2010); Judith Treas, Can Families Compensate for Welfare State Retrenchment?, 41 CONTEMP. Soc. 33 (2012).

41. See, e.g., Suzanne Mettler, Reconstituting the Submerged State: The Challenges of Social Policy Reform in the Obama Era, 8 PERSP. POL. 803 (2010); BRAITHWAITE, supra note 1; Black, supra note 24; Levi-Faur \& Jordana, supra note 6.

42. See Lobel, supra note 25 , at 363 .

43. See Levi-Faur, supra note 36 .

44. Colin Scott, Regulation in the Age of Governance: The Rise of the Post-Regulatory State, in The Politics of Regulation 145, 148-49 (Jacint Jordana \& David Levi-Faur eds., 2004).

45. BRAITHWATte, supra note 1 , at vii-x. 
generations. As a result, new governance's boundaries, like those of corporate governance, are assumed to be "blurred and porous," 46 as well as in a state of disequilibrium, ${ }^{47}$ which allows for a high level of pragmatic "experimentalism" 48 within new governance's learning processes. ${ }^{49}$ All of this points to the hopefulness of publicizationhopefulness this article wishes to temper.

Below, this article introduces a number of literatures on governance, which help to construct a greater appreciation of some of the thoughts that have influenced the form new governance appears to be taking. As Orly Lobel suggests, new governance accepts "both market and governance failures" and challenges "conventional wisdom," finding "a third-way vision between unregulated markets and top-down government controls." 50 In particular, it challenges the notion that governments have removed regulations from areas of society, and have allowed markets to operate "freely." 51 This notion of deregulation has

46. John R. Boatright, The Implications of the New Governance for Corporate Governance, in CORPORATE CITIZENSHIP AND NEW GOVERNANCE 133, 141 (Ingo Pies \& Peter Koslowski eds., 2011). Ball and Junemann discusses how governance, by its nature, deconstructs or transcends organizational boundaries and not how these networks are changes alluding to the understanding of regulated spaces that a governmentality approach might offer, creating "overlap and confusion." See STEPHEN J. BALL \& CAROLINA JUNEMANN, NETWORKS, NEW GOVERNANCE AND EDUCATION 1-7 (2012).

47. Dewey believed that learning occurred by facing an experience of disequilibrium and then finding a "more extensive balance," arguing "[e]quilibrium comes . . . out of, and because of, tension." JOHN DEWEY, ART AS EXPERIENCE 14 (1934). In this sense, life and learning to Dewey was a constant cycle of equilibrium and disequilibrium.

48. For more on the issues related to new governance and experimentalism, see generally Gráinne de Búrca, New Governance and Experimentalism: An Introduction, 2010 WIS. L. REV. 227.

49. See Solomon, supra note 15, at 593-97. In the European context, democratic experimentalism is occurring within the European Union in relation to the coordination of top-down, as well as bottom-up, learning processes. See Erika Szyszczak, Experimental Governance: The Open Method of Coordination, 12 EuR. L.J. 486, 496 (2006).

50. Lobel, supra note 18 , at 65.

51. For more on this idea and the regulation literature, see, for example, MiLToN Friedman, Capitalism and Freedom (1962); Paul Stephen Dempsey \& Andrew R. Goetz, Airline Deregulation and LaISSEZ-Faire MYthology (1992); Martha DerThick \& PaUl J. QUiRK, The Politics of Deregulation (1985); DaN IMMERgluCK, FORECLOSED: High-RISK LENDING, DEREGULATION, AND THE UNDERMINING OF AMERICA'S Mortgage Market (2009); Paul L. Joskow, Deregulation (2009); Yergin \& STANISLAW, supra note 2. Additionally, consider this quotation from Mark Weisbrot, an economist at the progressive Center for Economic and Policy Research: "Friedman had an enormous impact on the shape of most economies in the world in the last 25 to 35 years'... . 'If you go back to his book Capitalism and Freedom ... it wasn't even reviewed by major reviewers like the New York Times. By the end of Reagan's last term, most of his policies were implemented[.]'. . . 'Friedman fought a counterrevolution in the 1950s against Keynesianism ...." Nobel Economist Milton Friedman Dead at 94, CNN MONEY (Nov. 16, 2006, 6:16 PM), http://money.cnn.com/2006/11/16/news/newsmakers/friedman/. 
been largely debunked. ${ }^{52}$ Not only has the administrative state grown in size (and expense), ${ }^{53}$ but there has also been a vast geographical expánsion of regulations in previously unregulated, or less regulated, spaces. ${ }^{54}$ Thus, such notions, which framed much of the conversation about the shift from the welfare state for so long, ${ }^{55}$ are inaccurate as a description of the evolution of government and governance. ${ }^{56}$ Much of the literature on governance that supports, or supported, the evolution of new governance draws on this insight, as will be seen below.

\section{A. Privatization}

The privatization literature ${ }^{57}$ describes the "withdrawal of the state" as a provider of public services and, in particular, various forms of social insurance. ${ }^{58}$ The narrative of privatization is more dramatic and selfapparent in countries such as the United Kingdom (which, during the "Golden Age," had a more robust welfare state than the United States), ${ }^{59}$ but it still strongly shapes how many understand this regulatory shift in the United States. ${ }^{60}$

Privatization generally refers to the outsourcing of government services ${ }^{61}$ - $" e s s e n t i a l$ services" 62 - that the state traditionally provided

52. See AYrEs \& BRAITHWAITE, supra note 5, at 7-12; BRAITHWAITE, supra note 1, at 412; Levi-Faur, supra note 23, at 13-14.

53. See Braithwaite, supra note 4 , at 8,18 .

54. See Levi-Faur, supra note 23 , at 12-13.

55. See generally AYRES \& BRAITHWAITE, supra note 5.

56. See Braithwaite, supra note 4, at 8-12.

57. See generally Kate Ascher, The Politics of Privatisation (1987); Friedman, supra note 51; The Political EConomy of Privatization (Thomas Clarke \& Christos Pitelis eds., 1993); YERGIN \& STANISLAW, supra note 2; Maxim Boycko et al., A Theory of Privatisation, 106 ECON. J. 309 (1996).

58. Scott, supra note 44 , at $148-49$ (emphasis omitted).

59. Id.

60. PaUl R. Verkuil, Outsourcing Sovereignty: Why Privatization of

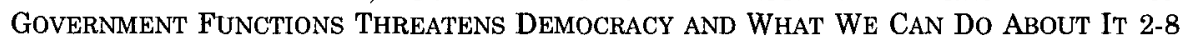
(2007).

61. For more on privatization in this sense, see Damian Grimshaw et al., Going Privately: Partnership and Outsourcing in UK Public Services, 80 PUB. ADMIN. 475, 475-76 (2002); Dru Stevenson, Privatization of Welfare Services: Delegation by Commercial Contract, 45 ARIZ. L. REV. 83, 83-85 (2003). See also Andrew Kakabadse \& Nada Kakabadse, Outsourcing in the Public Services: A Comparative Analysis of Practice, Capability and Impact, 21 PUB. ADMIN. \& DEV. 401 (2001).

62. For the challenge of how to govern privatized essential services, see generally GREG Palast et al., DEmocracy and REgulation: How the Public CaN Govern Essential SERVICES (2003). These authors have a broader definition of essential services than the definition of essential services in which the right to strike is highly limited. See, e.g., A. 
through welfare programs, like the New Deal programs, to for-profit or nonprofit organizations. ${ }^{63}$ The rationale for privatization is, in essence, that it improves the efficiency of social services provided by allowing private, usually for-profit, organizations to manage them. ${ }^{64}$ By delegating responsibility, governments achieve provision of more services at a decreased expense to the public by allowing free market capitalism to shoulder much of the load.65 The main claim is that the consumers of these services receive better quality and variety of products, as well as potentially lower prices generated by the efficiency gains from market competition. ${ }^{66}$ These efficiency gains increase the profitability of providing services and boost economic growth, ultimately leading to more financially stable economies. ${ }^{67}$ Economic growth increases the tax base, and these gains made by governments are then passed down to taxpayers, reducing the overall tax burden. ${ }^{68}$ Low taxes leave more money in the economy, further increasing economic growth. ${ }^{69}$ In the end, taxpayers enjoy lower tax burdens, consumers

Pankert, Settlement of Labour Disputes in Essential Services, 119 INT'L LAB. REV. 723, 723-24 (1980).

63. Stevenson, supra note 61 , at $86-94$; see also Aman, supra note 17. For a more in depth discussion of the appropriate role for nonprofits and for-profits in programs that are social services that have been outsourced by government, see generally William P. Ryan, The New Landscape for Nonprofits, in NONPROFIT GoverNANCE AND MANAGEMENT 13 (Victor Futter et al. eds., rev. ed. 2002); Eric Werker \& Faisal Z. Ahmed, What Do Nongovernmental Organizations Do?, 22 J. ECON. PERSP. 73 (2008).

64. See Catherine Eckel et al., Privatization and Efficiency: Industry Effects of the Sale of British Airways, 43 J. Fin. ECON. 275, 297 (1997); William L. Megginson \& Jeffry M. Netter, From State to Market: A Survey of Empirical Studies on Privatization, 39 J. EcoN. LitERATURE 321, 380-81 (2001). However, this assertion is contested. See, e.g., Shinichi Nishiyama \& Kent Smetters, Does Social Security Privatization Produce Efficiency Gains?, 122 Q.J. ECON. 1677 (2007); George Yarrow et al., Privatization in Theory and Practice, 1 ECON. POL'Y 323 (1986) (arguing that the benefits of privatization can often be achieved through better means).

65. YERGIN \& STANISLAW, supra note 2, at 372-74.

66. See, e.g., id. at 373-74; Eckel et al., supra note 64.

67. For a more detailed understanding, see, for example, YERGIN \& STANISLAW, supra note 2, at 372-74. Additionally, consider the "Washington Consensus." See generally John Williamson, What Washington Means by Policy Reform, in LATIN AMERICAN ADJUSTMENT 5 (John Williamson ed., 1990).

68. For a more detailed understanding of this in a modern context, as well as an analysis of whether such a policy truly works, see HANG NGUYEN ET AL., TAX POLICY CTR., How Hard is it to Cut TaX Preferences to Pay for lower Tax Rates? (2012), available at http://www.taxpolicycenter.org/UploadedPDF/412608-Base-Broadening-toOffset-Lower-Rates.pdf.

69. Generally, "[c]orporate taxes are found to be most harmful for growth, followed by personal income taxes, and then consumption taxes." Asa Johansson et al., Taxation and Economic Growth 2 (OECD Econ. Dep't, Working Paper No. 620, 2008), available at http://dx.doi.org/10.1787/241216205486. 
enjoy better services, employees benefit from a better economy, and governments can channel resources with more focus on a narrower range of functions. ${ }^{70}$

Unfortunately, this theory has already proven too good to be true. Policies have modified privatization by applying it in a more incremental, experimental, and responsive manner ${ }^{71}$ than the initial enthusiasm encouraged by the failed "Washington Consensus."72 Still, skepticism remains as to whether privatization can be implemented in a manner that adequately offsets risks to the public interest in delegating discretion over the management of large segments of society to for-profit actors. ${ }^{73}$ The issue of how to exploit the benefit of privatization while mitigating its risks is a central struggle within the new governance literature.

\section{B. Risk Society and Reflexive Government}

During the time of the welfare state (approximately from the first Roosevelt Administration in 1933-1937 until between the Carter Administration in 1977-1981 and the first Reagan Administration in 1981-1985), ${ }^{74}$ a prevailing assumption, at least in the earlier years, was that an effective regulatory architecture could be modeled on commandand-control style regulation. ${ }^{75}$ For instance, Adolf Berle, who was a central figure in Franklin D. Roosevelt's Brain Trust, predicted that government experts could employ science to determine what the law ought to be, while administrative and judicial technologies could enforce the regulatory architecture devised to implement the law. ${ }^{76}$ Like 2.

70. For a more detailed understanding, see generally YERGIN \& STANISLAW, supra note

71. See generally John Bennett et al., Methods of Privatization and Economic Growth in Transition Economies, 15 ECON. TRANSITION 661 (2007); THE WORLD BANK, ECONOMIC GROWTH IN THE 1990S: LEARNING FROM A DECADE OF REFORM 165-95 (2005), available at http://www 1.worldbank.org/prem/lessons1990s/.

72. See Dani Rodrik, Goodbye Washington Consensus, Hello Washington Confusion? A Review of the World Bank's Economic Growth in the 1990s: Learning from a Decade of Reform, 44 J. ECON. LITERATURE 973 (2006); see also YERGIN \& STANISLAW, supra note 2, at 237; Williamson, supra note 67 (including additional comments to Williamson's article).

73. See Rodrik, supra note 72 , at 986.

74. Salamon argues that "the Carter administration began in the latter $1970 \mathrm{~s}$ to restrain the growth of government social welfare spending" in response to increased fiscal deficits. Lester M. Salamon, The Marketization of Welfare: Changing Nonprofit and ForProfit Roles in the American Welfare State, 67 Soc. SERV. REV. 16, 20-21 (1993).

75. See, e.g., Adolf A. Berle, Jr., Government Function in a Stabilized National Economy, 33 AM. ECON. REV. 27 (1943).

76. See, e.g., id. at 37 . 
others, ${ }^{77}$ Berle made assumptions about natural hazards and manufactured risks and how they related to science and its technologies. However, these proved to be overly optimistic, simplistic, ${ }^{78}$ and more problematic than anticipated. 79

Anthony Giddens suggests that the manufacturing of uninsurable risk by progress, and not the financial cost of the welfare state, led to state retrenchment. ${ }^{80}$ The state was unable to devise a way to use regulatory architecture to solve the problems created by progress. ${ }^{81}$ Faced with this, governments were caught between a rock and a hard place: the social experiment of using the welfare state to mitigate the dangers of progress was unworkable, and the prospect of reverting to a pre-progress, pre-industrial society was similarly impractical. Thus, the social contract, which obliged the state to mitigate the social and environmental risks caused by industrialization, was in breach. ${ }^{82}$ The state could not meet these lofty commitments. As a result, the first project of "embedded liberalism" was a failure and the state retreated. 83 From this perspective, the welfare state model proved unable to adequately identify risks or adequately devise solutions that did not manufacture new risks and greater complexity. ${ }^{84}$ This inability left "the path of progress" 85 highly uncertain, ${ }^{86}$ and this uncertainty ultimately led to the demise of the welfare state and to the rise of privatization. ${ }^{87}$

With no way back and no way forward, the state retrenched, resulting in what Ulrich Beck, Giddens's colleague, calls "reflexive

77. See generally Kerry Rittich, Functionalism and Formalism: Their Latest Incarnations in Contemporary Development and Governance Debates, 55 U. TORONTO L.J. 853 (2005).

78. See generally BECK, supra note 22; Beck et al., supra note 22.

79. See, e.g., Robert L. Rabin, Federal Regulation in Historical Perspective, 38 STAN. L. REV. 1189, 1318 (1986) (referring to a failure to consider the costs and benefits of various regulatory options).

80. Anthony Giddens, Risk and Responsibility, 62 MOD. L. REV. 1, 4-10 (1999).

81. See id.

82. See generally BECK, supra note 22.

83. For more on the idea of "embedded liberalism," see, for example, Andrew T.F. Lang, Reconstructing Embedded Liberalism: John Gerard Ruggie and Constructivist Approache's to the Study of the International Trade Regime, in EMBEDDING GLOBAL MARKETS 13 (John Gerard Ruggie ed., 2008); Jeffrey A. Hart \& Aseem Prakash, The Decline of 'Embedded Liberalism' and the Rearticulation of the Keynesian Welfare State, 2 NEW PoL. ECON. 65 (1997); Ruggie, supra note 35.

84. See Giddens, supra note 80 , at 9-10.

85. For the phrase's origin, see generally MICHAEL J. TREBILCOCK \& RONALD J. Daniels, Rule Of Law Reform And Development: Charting the Fragile Path of PROGRESS (2008).

86. See Beck et al., supra note 22, at 10-13 (referring to the unforeseeable and accidental future, and how it cannot be planned for or controlled).

87. See, e.g., id.; Giddens, supra note 80, at 4-10. 
modernization." 88 Mitchell Dean uses the term "reflexive government" as an alternative term for "reflexive modernity." ${ }^{89}$ Dean writes that reflexive government is "a folding back of the objectives . . . upon its means." 90 In other words, government legitimacy is now measured by the efficiency of how it provides services (means), not what services it provides (objectives), because as Giddens explained, the calculus of determining what services ought to exist has been exposed as unworkable. ${ }^{91} \mathrm{In}$ other words, governments are at a loss as to how to solve the challenges they face. As a result, they outsource responsibilities to the private sector and focus squarely on improving efficiency of the remaining regimes of practice within their purview of power to maintain legitimacy. ${ }^{92}$ As long as governments operate with a legitimate measure of accountability (a calculus of risk management and economic efficiency), ${ }^{93}$ the larger issue of whether such government initiatives promote the long-term sustainability of society can be shadowed by technocratic narratives. ${ }^{94}$ Thus, governments limit their function and fixate on the efficiency of their internal control systems as a measure of performance.

Accounting scholar Michael Power details how technocratic narratives "have filtered into regulatory organizations [providing] a blueprint for the governance and accountability of the regulatory decision process." 95 Power also agrees with the above-mentioned thinkers in this area that such patterns of reflexive government are leading to a new and potentially dangerous political economy. ${ }^{96}$

\section{Decentered Regulation}

The decentered literature covers a broad spectrum of ideology from neoclassical economic thinkers, such as Milton Friedman ${ }^{97}$ and Friedrich Hayek, ${ }^{98}$ to governance scholars with roots in responsive law,

88. BECK, supra note 22 , at 10 .

89. See Mitchell Dean, Governmentality: Power and Rule in Modern Society 208-12 (2d ed. 2010).

90. Id. at 207 .

91. See Giddens, supra note 80 , at 4-10.

92. See DEAN, supra note 89, at 207-08.

93. See Michael PoWer, Organized Uncertainty: Designing a World of Risk MANAGEMENT 2-7, 91 (2007).

94. See infra Part III, for more on technocratic narratives.

95. POWER, supra note 93 , at 91.

96. See id. at $91-92$.

97. See generally Milton Friedman \& Rose Friedman, Free to Choose: A PERsonal STATEMENT (1980).

98. See generally Hayek, supra note 16. 
such as John Braithwaite ${ }^{99}$ and David Levi-Fair, ${ }^{100}$ to those with roots in systems theory and reflexive law, such as Julia Black ${ }^{101}$ and Colin Scott. ${ }^{102}$

Friedman and Hayek, in particular, have become synonymous with predicting the failures of the welfare state. ${ }^{103}$ Historical narratives focused on their work have explained that governments, with the United States and United Kingdom leading the way, privatized and deregulated their regulatory models. ${ }^{104}$ Top-down, command-and-control regulatory techniques were abandoned, and "free markets" were unleashed. ${ }^{105}$ "Free markets," rhetoric aside, mean regulators create more discretionary, process-based regulation of markets and society, which allows private actors-generally for-profit actors-to exercise more discretion within regulated spaces. 106

One of the foundational claims of this neoclassical academic and political movement was that the "man on the spot" enjoyed the most intimate vantage point, and this helped him understand complex society. ${ }^{107}$ For this reason, some assumed that with the aid of the price mechanism, the "man on the spot" was in the best position to make decisions in regulated spaces. ${ }^{108}$ For instance, Hayek would likely suggest that Goldman Sachs does not need a centralized public bureaucracy to operate within the global economy. Goldman Sachs is the "man on the spot," having the most intimate knowledge of the ever-

\footnotetext{
99. See generally BRAITHWAITE, supra note 1.

100. See generally Levi-Faur \& Jordana, supra note 41.

101. See generally Black, supra note 24.

102. See generally Scott, supra note 44.

103. See YERGIN \& StANISLAW, supra note 2, at 80-81, 126-27.
}

104. See id. at 96-105 (describing, for example, how Margaret Thatcher was able to start and successfully carry out a privatization program in the United Kingdom). For an understanding of how these changes played out in the Canadian welfare state model, see generally H.W. Arthurs, Rethinking Administrative Law: A Slightly Dicey Business, 17 OsGoOdE HALL L.J. 1 (1979); H.W. Arthurs, Jonah and the Whale: The Appearance, Disappearance, and Reappearance of Administrative Law, 30 U. TORONTO L.J. 225 (1980); STATES Against MARKETS: The Limits OF Globalization (Robert Boyer \& Daniel Drache eds., 1996); Harry W. Arthurs, The Re-constitution of the Public Domain, in THE MARKET OR THE PUBLIC DoMAIN?: Global GovernaNCE AND THE ASYMMETRY OF PoWER 85 (Daniel Drache ed., 2001); Harry W. Arthurs, The Administrative State Goes to Market (and Cries 'Wee, Wee, Wee' All the Way Home), 55 U. Toronto L.J. 797 (2005); DaNiEL DrachE, Defiant Publics: The UnPRECEDENTEd REACH OF THE Global Citizen (2008); Harry Arthurs, The Hollowing Out of Corporate Canada: Implications for Transnational Labor Law, Policy and Practice, 57 BUfFalo L. REV. 781 (2009).

105. See, e.g., Milton Friedman, Free Markets and Free Speech, 10 HARV. J.L. \& PUB. POL'Y 1 (1987) (discussing the benefits of free markets and a free society).

106. See YERGIN \& STANISLAW, supra note 2, at 406-08.

107. Hayek, supra note 16 , at 524-25.

108. Id. 
changing information it must balance in its decisionmaking processes. As for the knowledge Goldman Sachs lacks, Hayek would argue that no actor enjoys perfect knowledge, but the price mechanism adequately supplements these limits by providing information about other market actors. ${ }^{109}$

The "man on the spot" is plugged into the knowledge of the facts on the ground. As such, groups of these actors are collectively, from various decentralized locations, in the best positions to exercise governance discretion, since each has an intimate knowledge of the small segment of the regulated space in which each operates. ${ }^{110}$ Consequently, by exploiting the power of information exchange technologies (such as the price mechanism, ${ }^{111}$ knowledge brokers, and auditing and reporting processes ${ }^{112}$ ), regulators can create "knowledge networks,"113 which provide decentered actors the additional information they need to coordinate activities, and accordingly govern society.

This sort of thinking emphasizes that an important dimension of an effectively regulated space is the willingness of those regulated to respect, follow, and actively participate (to the best of their ability) as partners in the regulatory process. ${ }^{114}$ In fact, such governance strategies are regarded as dependent on the information that exchanges between regulators and the regulated to learn of and respond to complex

109. Id.

110. Of course, this extends beyond what Hayek was suggesting, but one may imagine how this applies to Hayek's knowledge theory. See generally Hayek, supra note 16.

111. See id. at 524-28.

112. Knowledge brokers are people or organizations that act as intermediaries between the different manufacturers of knowledge, providing linkages and resources. They are conduits for channeling information through a social network (like a regulated space). For more on knowledge brokers, see, for example, Andrew B. Hargadon, Brokering Knowledge: Linking Learning and Innovation, 24 RES. ORG. BEHAV. 41 (2002); Andrew B. Hargadon, Firms as Knowledge Brokers: Lessons in Pursuing Continuous Innovation, 40 CAL. MGMT. REv. 209, 210-11 (1998); Gianmario Verona et al., Innovation and Virtual Environments: Towards Virtual Knowledge Brokers, 27 ORG. STUD. 765, 765 (2006).

113. The use of the term "knowledge network" is as an analogy to other literatures that use the term. For instance, some have explored the idea of a "knowledge network" for coordinating and management at the organization level. See, e.g., Andreas Seufert et al., Towards Knowledge Networking, 3 J. KNOWLEDGE MGMT. 180 (1999); William Swan et al., Viewing the Corporate Community as a Knowledge Network, 5 CORP. COMM. 97 (2000). Others think of it in a most literal sense as a bank of knowledge that still has coordinating and management application potential, but not so much in the classical regulatory sense. See, e.g., Sandy J. Andelman et al., Understanding Environmental Complexity Through a Distributed Knowledge Network, 54 BIOSCIENCE 240 (2004); Martin Doerr \& Dolores Iorizzo, The Dream of a Global Knowledge Network-A New Approach, 1 J. CompUTING \& CULTURAL HERITAGE 1 (2008).

114. See BRAITHWAITE, supra note 1, at 88-97. 
regulatory challenges in a timely and effective manner ${ }^{115}$ or, more dramatically, simply to avoid regulatory failure.

Since such information exchanges between actors within a regulated space need to be effective, maintaining nonadversarial relationships is given a top priority to facilitate communication, coordination, and learning. ${ }^{116}$ The problem is that this priority can hamper meaningful enforcement mechanisms in some cases as the regulator becomes fearful that paternalistic punishment of the regulated may undermine their partnership, thus compromising the information exchanges within the regulated space. ${ }^{117}$ This places the regulator in a dilemma: if it wishes to have effective information exchanges so as to have the best possible knowledge about a regulated space, then it must not enforce such regulation with vigor because it may alienate the regulated, on whom it relies to inform it about changes in the regulated space. ${ }^{118}$ On the other hand, if a regulator does not enforce its regulations, or has regulations without "real teeth," then the regulated may not take the "law" of the regulated space seriously, 119 creating new informal norms, which can dictate how the regulated space functions and can thus compromise the regulator's intentions. ${ }^{120}$

From this perspective, governance is a channeling of discretionary authority from government agencies to more hybrid and decentered public-private governance processes, ${ }^{121}$ in the hope of establishing social relationships with "the man on the spot." 122 This channeling is deemed necessary to exploit decentered decisionmaking through information exchange technologies. ${ }^{123}$ This results in the replacement of substancebased, state-imposed regulation with process-based, public-private coregulation and co-governance. ${ }^{124}$

115. See id. at $65,70,79$.

116. See id. at 88-97.

117. See id.

118. See id.

119. See, e.g., Clark J. Lee, Federal Regulation of Hospital Resident Work Hours: Enforcement with Real Teeth, 9 J. HEALTH CARE L. \& POL'Y 162 (2006) (highlighting the need for federal regulation of working hours for medical residents and interns to ensure adequate implementation and enforcement).

120. This is what Coffee suggested happened with the Credit Crisis and the shift in leverage regulation of banks. See Coffee, supra note 13, at 1-2.

121. See BRAITHWATtE, supra note 1, at 7-8.

122. Hayek, supra note 16 , at 524 (internal quotation marks omitted).

123. See Black, supra note 24 , at 103-05 (discussing the proposition that governments should not have a monopoly on regulation over social actors).

124. See generally THE Politics of REgulation, supra note 44. For the resulting dangers of this practice, see Philip Alston, Facing Up to the Complexities of the ILO's Core Labour Standards Agenda, 16 EUR. J. INT'L L. 467 (2005). 
Governments restrict their function to devising strategic plans for regulated spaces (called steering), leaving a large portion of the application, monitoring, and enforcement of these strategies (called rowing) to nonstate actors. ${ }^{125}$ As a result, regulation is becoming intimately linked to other ordering processes. such as markets, civil society networks, and the internal control and risk management mechanisms of corporate governance. ${ }^{126}$ In theory, the state creates the steering rules, but in practice this is only partly true since private participation in strategic rulemaking is becoming more common in regulated spaces. ${ }^{127}$ Consequently, the distinction between steering and rowing is blurred. ${ }^{128}$

When looking at such regulation, for instance the California Occupational Safety and Health Act Cooperative Compliance Plan, ${ }^{129}$ it is not so easy to draw a distinction between the Act's regulations (steering) and the rules emerging from the regulated (rowing). ${ }^{130} \mathrm{Many}$ of the rowing norms are also strategic and steering in nature. The blurring between external institutional norms (strategic steering regulations) and internal organizational norms (operational rowing norms) demonstrates that the differentiation between who is steering and who is rowing is not so clear. ${ }^{131}$ In such heterarchically regulated spaces, assumptions cannot be made regarding which norms, control mechanisms, and regulatory participants are, in fact, directing the evolution of regulatory norms at any given time. ${ }^{132}$ Upon reflection, one might pause and conclude that this evolution of heterarchically regulated spaces is a sign of publicization; however, that might be premature. Without any empirical evidence that these for-profit private

125. See Levi-Faur, supra note 23, at 15-16.

126. To be clear, although state law will always be present within post-statist regulatory processes, it becomes a question of whether the law is steering these regulatory processes or whether these regulatory processes are steering themselves.

127. See Harter, supra note 20, at 414-22 (identifying the considerable benefits yielded from the collaboration of private and public actors in creating policy).

128. See id.; PowER, supra note 93, at 41-42.

129. For more details on the plan, see Brian Friel, OSHA: Cooperative Compliance, GOV'T EXECUTIVE (Dec. 8, 1997), http://www.govexec.com/federal-news/1997/12/oshacooperative-compliance/5176/.

130. For a general understanding of the situation, see PowER, supra note 93, at 36-42. For an analysis of the benefits and pitfalls of the strategy of the Occupational Safety and Health Act, see, for example, Marius Aalders \& Ton Wilthagen, Moving Beyond Command-and-Control: Reflexivity in the Regulation of Occupational Safety and Health and the Environment, 19 LAW \& POL'Y 415 (1997); Orly Lobel, Interlocking Regulatory and Industrial Relations: The Governance of Workplace Safety, 57 ADMIN. L. REV. 1071 (2005).

131. See BRAITHWAITE, supra note 1, at 8 (noting the "reality of hybridity between the privatization of the public and publicization of the private").

132. See Scott, supra note 44 , at $146,154$. 
actors, who have stepped into the traditional role of a governmental agency, are, as Freeman put it, "increasingly commit[ing] themselves to traditionally public goals," 133 this cannot be assumed to be more than merely privatization without publicization.

Regulatory architects within these heterarchically regulated spaces are experimenting with reflexive, ${ }^{134}$ responsive, ${ }^{135}$ decentered, ${ }^{136}$ and collaborative $^{137}$ techniques to harness incentive mechanisms, many times market-based ones. ${ }^{138}$ The umbrella term "regulatory capitalism" captures many of these dimensions of decentered governance. ${ }^{139}$ Looking forward, future regulated spaces may host co-governance mechanisms in which the state, although present, plays a minor role. Such spaces of the future have been associated with an understanding of the "postregulatory state." 140 Many elements of this post-regulatory state exist today, including auditing and reporting mechanisms, ${ }^{141}$ as well as the incorporation of private monitoring of regulated spaces by nonstate gatekeepers. ${ }^{142}$ These gatekeepers can dwell in civil society, much like People for the Ethical Treatment of Animals, ${ }^{143}$ or in the business sector, such as Moody's Investors Services. ${ }^{144}$ Proliferation of these mechanisms is the most obvious sign of this emerging decentered order. ${ }^{145}$ But the question remains: Will these private actors have the

133. Freeman, supra note 3 , at 1285 .

134. See, e.g., Gunther Teubner, Substantive and Reflexive Elements in Modern Law, 17

LAW \& SOC’Y REV. 239 (1983); Zumbansen, supra note 22.

135. See, e.g., AYRES \& BRAITHWAITE, supra note 5.

136. See, e.g., Black, supra note 24.

137. See, e.g., Freeman, supra note 20.

138. See, e.g., Richard B. Stewart, Models for Environmental Regulation: Central Planning Versus Market-Based Approaches, 19 B.C. ENVTL. AFF. L. REv. 547, 548 (1992).

139. See, e.g., David Levi-Faur, Regulatory Architectures for a Global Democracy: On Democratic Varieties of Regulatory Capitalism, in The Challenges of Global Business AUTHORITY 205 (Tony Porter \& Karsten Ronit eds., 2010); David Levi-Faur, Varieties of Regulatory Capitalism: Sectors and Nations in the Making of a New Global Order, 19 GOVERNANCE 363 (2006); Levi-Faur \& Jordana, supra note 41.

140. Scott, supra note 44 , at 146.

141. See Power, supra note 93 , at 53, 90, 152-81; see also MiCHAEL Power, THE AUdiT SOCIETY: RITUALS OF VERIFICATION (1997).

142. See John C. Coffee, Jr., Brave New World?: The Impact(s) of the Internet on Modern Securities Regulation, 52 BUS. LAw. 1195, 1210-13, 1232-33 (1997); John C. Coffee, Jr., Gatekeeper Failure and Reform: The Challenge of Fashioning Relevant Reforms, 84 B.U. L. REV. 301, 305-07, 334-35 (2004).

143. See How Is a Company Certified as Cruelty-Free?, PETA, http://www.peta.org/about/faq/how-is-a-company-certified-as-cruelty-free.aspx (last visited Mar. 31, 2014) (classifying as "cruelty-free" those companies that have signed PETA's statement of assurance or provided a statement that they do not conduct animal testing).

144. MOODY's, http://www.moodys.com/ (last visited Apr. 1, 2014).

145. See generally POWER, supra note 93; POWER, supra note 141; MICHAEL POWER, THE RISK MANAGEMENT OF EVERYTHING: RETHINKING THE POLITICS OF UNCERTAINTY (2004). 
requisite public spiritedness to sacrifice self-interest when called upon to do so?

\section{Conclusion}

Faith in the reassertion of the public interest within governance appears in works of conscientious governance theories like those of Braithwaite and Freeman, suggesting that a counterbalance to privatization is occurring. ${ }^{146}$ The hope is that, as the bright-line distinction between public and private blurs further, some of the rationalities that legitimate profitmaking on the cusp of legality ${ }^{147}$ will be brought under more scrutiny by the "unwieldy" public148 and academics, ${ }^{149}$ resulting in for-profit actors becoming more societally minded.

Linguistically, regulatory scholars have introduced the language of "public-private partnership"150 and "governance"151 into the lexicon of

146. See generally BRAITHWAITE, supra note 1; Freeman, supra note 3; Braithwaite, supra note 4, at 8,18 ; Braithwaite, supra note 7 .

147. See Frank H. Easterbrook \& Daniel R. Fischel, The Economic Structure of CORPORATE LAW 38-39 (1991).

148. See, e.g., Talking About a Revolution, Economist, Apr. 7, 2012, available at http://www.economist.com/node/21552179; Rage Against the Machine, ECONOMIST, Oct. 22, 2011, available at http://www.economist.com/node/21533400.

149. See, e.g., David Vogel, The Market for Virtue: The Potential and Limits of Corporate SocIal Responsibility (2005); THE New Corporate ACCOUNTABILITY: CORPORATE SOCIAL RESPONSIBILITY AND THE LAW (Doreen McBarnet et al. eds., 2007); Ruth V. Aguilera et al., Putting the S Back in Corporate Social Responsibility: A Multilevel Theory of Social Change in Organizations, 32 ACAD. MGMT. REV. 836 (2007); Aaron K. Chatterji \& Barak D. Richman, Understanding the "Corporate" in Corporate Social Responsibility, 2 HARV. L. \& PoL'Y REV. 33 (2008); Peer Zumbansen, Rethinking the Nature of the Firm: The Corporation as a Governance Object, 35 SEATTLE U.L. REV. 1469 (2012).

150. See generally PUBlic-Private PARTNERShIPS: MANAGING RISks AND OpPoRTUNITIES (Akintola Akintoye et al, eds., 2003); PUBlic-PrIVATE PARTNERShIPS: Theory and Practice in International Perspective (Stephen P. Osborne ed., 2000); E.S. Savas, Privatization and PUblic-Private Partnerships (2000); Wolfgang Kleinwœchter, From Self-Governance to Public-Private Partnership: The Changing Role of Governments in the Management of the Internet's Core Resources, 36 LOY. L.A. L. REV. 1103 (2003); Chris Skelcher, Public-Private Partnerships and Hybridity, in THE OXFonD HandBook of Public Management 347 (Ewan Ferlie et al. eds., 2005); Gerry Stoker, Public-Private Partnerships and Urban Governance, in PARTNERSHIPS IN URBAN GovernanCE: EuROPEAN AND AMERICAN EXPERIENCE 34 (Jon Pierre ed., 1998); Aidan R. Vining \& Anthony E. Boardman, Public-Private Partnerships: Eight Rules for Governments, 13 PUB. WORKS MGM'T. \& POL'Y 149 (2008).

151. See generally THE TOOLS OF Government: A Guide to THE NEw Governance (Lester M. Salamon ed., 2002); Jody Freeman, The Private Role in Public Governance, 75 
discourse. Politically, a "double movement"152 against privatization and deregulation has increased support globally for greater accountability of for-profit actors. ${ }^{153}$ Vocationally, a strong corporate social responsibility discourse has entered into many top U.S. business schools. 154 But functionally, there is scant evidence to support the claim that for-profit actors are assuming the role of public servants, and yet faith in the publicization of for-profit activities within governance remains strong. ${ }^{155}$ This, in part, exposes a fragility in the new governance project: the potential that the hope of publicization makes privatization more palatable, but no less threatening to public interest.

So, is this faith in publicization misplaced? Jody Freeman's account of publicization assumes that private actors promise to uphold "traditionally public goals," because this is "the price" governments demand in order for these private actors to have access to these "lucrative opportunities."156 Does privatization play out under these conditions? Are governments generally in the position to make such demands? Short of having to cope with a political crisis of catastrophic proportions, are governments willing and able to reverse privatization initiatives merely because they are disappointed with the performance of private actors?

Some suggest not, arguing that the state withdrew from being a service provider because it could not afford to provide such services. ${ }^{157}$ This is a story of governments amassing debt in a manner that no financially prudent and socially conscious citizen with an eye to the

N.Y.U. L. REv. 543 (2000); B. Guy Peters \& John Pierre, Governance Without Government? Rethinking Public Administration, 8 J. PUB. ADMIN. RES. \& THEORY 223 (1998).

152. PoLANYI, supra note 35 , at $79,136$.

153. See Talking About a Revalution, supra note 148; Rage Against the Machine, supra note 148.

154. Top U.S. business schools with a new emphasis on Corporate Social Responsibility include: University of Michigan (Ross), Yale School of Management, Stanford Graduate School of Business, Notre Dame (Mendoza), University of California Berkeley (Haas), New York University (Stern), Columbia Business School, University of Virginia (Darden), Cornell (Johnson), and George Washington University School of Business. Cindy Hoots, The Aspen Institute's Top 10 Business Schools Integrating Corporate Social Responsibility, INSPIRED ECONOMIST (Oct. 21, 2009), http://inspiredeconomist.com/2009/10/21/the-aspeninstitutes-top-10-business-schools-focused-on-corporate-social-responsibility/.

155. Braithwaite, supra note 7 , at 4 .

156. Freeman, supra note 3, at 1285.

157. For a historical perspective post-Bretton Woods, see ThOMAS L. Friedman, The LEXUS AND THE OLIVE TREE (rev. ed. 2000). For a more contemporary view on the fiscal pressures facing the state, see Reuven S. Avi-Yonah, Globalization, Tax Competition, and the Fiscal Crisis of the Welfare State, 113 HARV. L. REV. 1573 (2000). 
welfare of the next generation could tolerate, ${ }^{158}$ so they were forced to privatize. This would not appear to be a situation in which private actors would be fearful that a government might reverse privatization, if private actors failed to uphold traditionally public goals.

That said, this financial justification for state withdrawal may not be altogether convincing, considering that, in the U.S. context, every administration, both Democratic and Republican, since the Reagan Administration has increased the national debt. ${ }^{159}$ In fact, the Reagan Administration, which to many represents the model for fiscal responsibility, did not decrease the overall national debt during its two terms. ${ }^{160}$ Either way, considering the massive amount of national debt in the United States, it appears unlikely that private actors need be too fearful that the government will reverse privatization-at least in the U.S. context.

Placing the issue of financial capacity to one side, both the risk and decentered regulation literatures suggest that governments cannot reverse privatization because government experts alone cannot determine how to regulate society. In short, governments need privatization-or at least private actors-to participate in exercising governance discretion from various decentralized locations because, as the decentered governance literature suggests, these actors possess an intimate and detailed knowledge of a segment of the regulated space, which government actors need to effectively understand and manage society. ${ }^{161}$ Thus, the idea that publicization is the price that governments demand for private actors to have access to "lucrative opportunities" may not be accurate. The more frightening possibility, and possibly the more accurate one, is precisely the opposite: privatization is the price that private actors demand to allow for governments to govern adequately.

\section{THE Gates OF CORPORATE GOVERNANCE}

There are a number of rudimentary ideas that have become anchors for how judges, lawyers, and corporate legal scholars understand the

158. See, e.g., OFFICE OF MGMT. \& BUdGET, HiSTORICAL TABLES: BUdGET OF THE UNITED STATES GOVERNMENT, FISCAL YEAR 2013, at 5-10, 21-23 (2013), available at http://www.whitehouse.gov/sites/default/files/omb/budget/fy2013/assets/hist.pdf.

159. Id. at 22-23 (charting the budget deficits from Reagan up to the present).

160. Braithwaite notes the financial analysis of Tramontozzi and Chilton, writing: "Overall, real business regulatory spending increased 10 per cent during the Reagan years." Braithwaite, supra note 4 , at 8.

161. Of course, this extends beyond what Hayek was suggesting, but one may imagine how this applies to Hayek's knowledge theory. See generally Hayek, supra note 16. 
corporation and the law that regulates it. This section introduces a number of them. Although this section presents each of these ideas in a largely uncontested manner, there are, of course, minority voices that contest them. ${ }^{162}$ That said, corporate legal scholars in the U.S. context tend to be more conservative than their European counterparts. Thus, American academics see many of the ideas presented below as commonsense positions. This position, on consideration, ought to make one pause to seriously consider, or reconsider, whether Corporate America is well suited or willing to assume the social responsibilities that a publicization of the corporation would entail.

\section{A. The Lex Mercatoria}

At its core, free market ideology suggests that if societies strive toward the ideal free market, many of today's social problems would be closer to being alleviated. ${ }^{163}$ Although many accept this without much investigation, the notion is rooted in the story of the medieval European merchant order. ${ }^{164}$ This order existed beyond state law. ${ }^{165}$ Accordingly, it was developed through custom and best practice. ${ }^{166}$ Merchants developed and administered their own laws, and the state rarely interfered.167 To many, it is a shining example of a period of a purer private ordering in which market mechanisms and social norms

162. See, e.g., William W. Bratton, Welfare, Dialectic, and Mediation in Corporate Law, 2 Berkeley Bus. L.J. 59 (2005); William Klein, Criteria for Good Laws of Business Association, 2 BERKELEY BUS. L.J. 13 (2005).

163. See FRIEDMAN, supra note 51, at 201-02 ("I believe that we shall be able to preserve and extend freedom. . . . But we shall be able to do so ... only if we persuade our fellow men that free institutions offer a surer . . . route to the ends they seek than the coercive power of the state."); MURRAY N. ROTHBARD, MAN, ECONOMY, AND STATE WITH POWER AND MARKET 1366 (2d ed. 2009) ("The more the market principle prevails in a society, therefore, the greater will be that society's freedom and its prosperity.").

164. López Rodríguez argues that during the Middle Ages, and for the following hundreds of years, uniform commercial rules were enforced through "the market tribunals of the various European trade centers." ANA M. LÓPEZ RODRÍGUEZ, LEX MERCATORIA AND HARMONIZATION OF CONTRACT LAW IN THE EU 87 (2003) (Den.).

165. It is suggested that these medieval uniform rules did not have the "benefit of state enforcement of contracts," but slowly "evolved their own private code of laws," which were enforced by a "local official or a private merchant." Paul R. Milgrom et al., The Role of Institutions in the Revival of Trade: The Law Merchant, Private Judges, and the Champagne Fairs, 2 ECON. \& POL. 1, 2 (1990).

166. This medieval merchant law, which developed privately through best practice, provides a model for how law might be constructed and implemented today. Robert $\mathrm{D}$. Cooter, Decentralized Law for a Complex Economy: The Structural Approach to Adjudicating the New Law Merchant, 144 U. PA. L. REV. 1643, 1647 (1996). See also Milgrom et al., supra note 165 , at 2.

167. See Cooter, supra note 166, at 1647; see also Milgrom et al., supra note 165, at 2. 
governed and society flourished. 168 This story of lex mercatoria (merchant law) celebrates the past prowess and future potential of the free market.

Although this story is not historically accurate, it still establishes a "common ground" for the proponents of the free market. 169 It is used as the model solution to solve social problems. ${ }^{170}$ Free market champions hold this image of the free market in their minds-and hearts-when they advocate for the protection of the freedom of contract, the inalienability of property, and minimal government intervention. ${ }^{171}$ Their arguments hint that a world without government is possible and desirable. ${ }^{172}$ Their views reflect a deep mistrust of government ${ }^{173}$ and a conviction that market function can spontaneously order complex society effectively. ${ }^{174}$ At the core of this free market ideology is the suggestion that the hand of equity, of government intervention, and of publicization is unnecessary because the visible hand of the market will provide equity if markets are allowed to operate freely. Meritocracy will take care of the rest. ${ }^{175}$ This faith in free market ideology loosely underpins much of corporate governance thinking.

\section{B. Corporate Law as Merely Protector of the Market Mechanism}

Much of corporate legal scholarship regards corporate law as the protector of the freedom of contract and the inalienability of property. Many think that, by simply protecting these fundamentals of market function, corporate law ensures that corporate management will be driven by competition to constantly strive for lower transaction costs and, as a result, greater efficiency within the corporation. ${ }^{176}$

168. See, e.g., Cooter, supra note 166, at 1647; see also FRIEDMAN, supra note 51 (applying this idea in a more general and obvious way).

169. Ralf Michaels, Legal Medievalism in Lex Mercatoria Scholarship, 90 TEX. L. REV. 259, 264 (2012).

170. See id.

171. See generally FRIEDMAN, supra note 51 (arguing that economic freedom is necessary for political freedom); ROTHBARD, supra note 163, at 1337-47.

172. See Bruce L. Benson, Enforcement of Private Property Rights in Primitive Societies: Law Without Government, 9 J. LIBERTARIAN STUD. 1 (1989); RoTHBARD, supra note 163.

173. See, e.g., F. A. HAYEK, THE ROAD TO SERFdOM (50th Anniversary ed. 1994).

174. See Hayek, supra note 16, at 519-20. Hayek claimed that markets lead to a "more efficient allocation of [societal] resources than any design could achieve." CHRISTINA Petsoulas, HaYeK's LibERALISM AND Its ORIGINS 2 (2001) (quoting F. A. HaYeK, New STUdies IN PHILOSOPHY, POLITICS, ECONOMICS AND THE HISTORY OF IDEAS 63-64 (1978)).

175. See Shikha Dalmia, The Fable of Market Meritocracy, ForbES MaGAzINE, Feb. 2010, available at http://www.forbes.com/2010/02/09/markets-finance-sarkozy-economicsopinions-columnists-shikha-dalmia.html.

176. EASTERBROOK \& FISCHEL, supra note 147 , at 35. 
Frank Easterbrook and Daniel Fischel explained that unlike administrative law, in which the discretion of administrative officials needs to be tightly constrained, corporate law does not have to police corporate managers in the same way. ${ }^{177}$ The reason is that there is already an enforcement mechanism in place-the market. ${ }^{178}$ If corporate managers do not do their jobs, then corporate profits decrease, which affects share price and results in ex ante contractual penalties for the managers. ${ }^{179}$ These penalties potentially include a decrease in the value of stock options, termination of employment, damage to reputation, and acquisition. 180

For the market mechanism to enforce efficient internal order within corporate governance, corporate law need only address the issues related to agency between shareholders and management- to be clear, corporate law need only ensure that corporate managers have one "master": shareholders. ${ }^{181}$ The market mechanism will do the rest. Otherwise, if corporate law directs corporate managers to have loyalties to both the investor and the community, the law would free managers from the discipline of the market, opening up the opportunity for them to serve neither. ${ }^{182}$

An idea that accompanies this thinking is that, for regulators to police corporate behavior, they need only harness the market. For instance, if a regulator imposes a large enough fine for a violation of a regulation, the regulator will have made effective use of the firm's strength. According to Easterbrook and Fischel, the firm's strength is in its ability to calculate risks and rewards, and, thus, imposing such a fine will effectively prevent violation of the regulation. ${ }^{183}$

Of course, this regulatory solution is not nuanced-effectively enforcing large fines against corporations-but it does provide an adequate rationale to protect the operation of the market mechanism within corporate governance. This is what is really at stake for corporate legal scholars like Easterbrook and Fischel-economic accountability to shareholders, not social responsibility. With this solution to regulatory challenges, the status quo corporate structure remains. In theory, the corporation is still encouraged to "maximize wealth" creation, ${ }^{184}$ while regulators have an effective mechanism to

177. Id.

178. Id. at $2-3,35$.

179. See id. at 6.

180. See id.

181. See id. at $37-38$.

182. Id. at 38 .

183. Id.

184. Id. 
alter behavior without reforming corporate law. ${ }^{185}$ This arrangement leaves "managers free to maximize the wealth of the residual claimants [shareholders] subject to the social constraints." 186

Upon reflection, Easterbrook and Fischel clearly established the public-private distinction within corporate law, explaining precisely where the iron gates against government intervention within corporate law ought to be constructed-at its very border. Most corporate legal scholars agree with Easterbrook and Fischel that corporate law best serves society as an economizing device that facilitates wealth creation and encourages corporate management to keep transaction costs low and profits high. ${ }^{187}$

\section{Corporate Law as the Product of the Market Mechanism}

In 1974, William Cary argued that states were competing to attract corporations to increase state revenues. ${ }^{188} \mathrm{He}$ thought that this was creating a dangerous "race to the bottom" for corporate governance standards. ${ }^{189}$ He suggested that Delaware, in particular, created corporate governance standards that favored managerial interests because corporate managers tended to be the incorporators, and the state's budget was dependent on revenues from corporations. ${ }^{190}$ As a consequence, state competition for corporations was resulting in managers enjoying broad and unchecked authority, resulting in lessthan-optimal corporate performance. ${ }^{191}$

In 1977, Ralph Winter wrote a reply to Cary, rejecting his position by arguing that state competition should "tend toward optimality so far as the shareholder's relationship to the corporation is concerned" and, thus, corporate governance standards, like those of Delaware, "are optimal legal arrangements." $192 \mathrm{He}$ agreed with Cary that corporate management ultimately had the consumer power over incorporation but argued that managers would select corporate law that reduced transaction costs and led to more profitable business organizations. ${ }^{193}$

185. For instance, fines or other sanctions by laws other than corporate law.

186. EASTERBROOK \& FISCHEL, supra note 147 , at 38.

187. See id. at $35-39$.

188. See William L. Cary, Federalism and Corporate Law: Reflections Upon Delaware, 83 YALE L.J. 663, 697 (1974).

189. Id. at 666 .

190. See id. at 670 .

191. See id. at 667-70.

192. Ralph K. Winter, Jr., State Law, Shareholder Protection, and the Theory of the Corporation, 6 J. LEGAL STUD. 251, 254 (1977).

193. See id. at $255-56$ 
Thus, state competition produced an optimal corporate law regime. ${ }^{194}$ Put differently, what Cary regarded as a "race-to-the-bottom," Winter regarded as a "race-to-the-top." 195

This debate has had a number of reincarnations, ${ }^{196}$ and Winter's position has consistently won the debate, creating the impression that corporate law is not a product of politics, but the product of market forces. ${ }^{197}$ Even though recent empirical evidence suggests that other states simply do not compete with Delaware for its primacy over incorporations for publicly held corporations in the United States, 198 the perception that U.S. corporate law is the product of market demands and competition between states still persists. ${ }^{199}$

When combined with the other normative messages addressed above, one can appreciate that many corporate legal thinkers are convinced that a corporate law shaped by market forces would lead to an optimal regime and that any political meddling, such as an attempt to publicize corporate governance, would be rejected out of hand as, at best, suboptimal and, at worst, as radical, unworkable, and blindly naïve.

\section{The Corporation as a Nexus of Contracts}

As regards corporate legal theory, it is important to stress from the outset that the concession theory, the entity theory, and the aggregate contractarian theory 200 always inform the legal understanding of the corporation. ${ }^{201}$ This is because the modern corporation has always

194. Id, at 254.

195. See id. at 255-58; Fenner Stewart, Jr., The Place of Corporate Lawmaking in American Society, 23 LoY. CoNSUMER L. REV. 147, 156 (2010).

196. See Stewart, supra note 195, at 155-57.

197. See id. at 157-64.

198. See Lucian Arye Bebchuk \& Assaf Hamdani, Vigorous Race or Leisurely Walk: Reconsidering the Competition over Corporate Charters, 112 YALE L.J. 553, 556 (2002); Marcel Kahan \& Ehud Kamar, The Myth of State Competition in Corporate Law, 55 STAN. L. REV. 679, 684 (2002).

199. See generally Stewart, supra note 195 (examining the growing skepticism in Delaware's optimal corporate law).

200. The concession theory asserts that corporations are merely creatures of statute. Fenner L. Stewart, Jr., Indeterminacy and Balance: A Path to a Wholesome Corporate Law, 9 Rutgers BuS. L. REV. 81, 95-96 (2012). The entity theory asserts that the corporation is something that exists beyond its aggregate parts. See id. at 99 . The aggregate contractarian theory argues that the corporation is the sum of the contractual obligations that each of its constituents (labor, management, shareholders, creditors, the community-at-large, etc.) owe to each of its other constituents. See id. at 120.

201. Id at 95. 
been $^{202}$ a group of aggregate constituents ${ }^{203}$ connected through contract, ${ }^{204}$ while at the same time, the corporation is an entity with personhood that only exists because of a concession made by the state. ${ }^{205}$ Today, in the U.S. legal context, the corporation is generally thought of in terms of a version of a theory overbalanced with a contractarian understanding of the corporation, ${ }^{206}$ which is captured by the nexus-ofcontracts theory. ${ }^{207}$ This article calls this the aggregate contractarian theory.

This imbalance within U.S. corporate theory conveys an understanding of the corporation as a set of consensual and efficient contracts that bind corporate constituents. ${ }^{208}$ This version of corporate theory suggests that a high level of efficiency occurs between corporate constituents because relaxed legal requirements allow market forces to inspire them to optimally negotiate contracts to satisfy their own interests. ${ }^{209}$ Since this arrangement is regarded as the best option for the corporation as an economizing device, ${ }^{210}$ it follows that corporate law

202. For a historical account of the rise of the modern corporation at the end of the nineteenth century, see Stewart, supra note 195, at 151-55.

203. Thomas W. Joo, Theories and Models of Corporate Governance, in CORPORATE GovernanCE: A SyNTHESIS OF THEORY, RESEARCH, AND PRACTICE 157, 159 (H. Kent Baker \& Ronald Anderson eds., 2010); see also Santa Clara Cnty. v. S. Pac. R.R. Co., 118 U.S. 394 (1886) (regarding the assessment of taxes on a consolidated railroad corporation).

204. Armen A. Alchian \& Harold Demsetz, Production, Information Costs, and Economic Organization, 62 AM. ECON. REV. 777, 783 (1972).

205. For more on the historical roots of the concession theory, see William W. Bratton, Jr., The New Economic Theory of the Firm: Critical Perspectives from History, 41 STAN. L. REV. 1471, 1502-05 (1989).

206. See generally Stewart, supra note 200.

207. See William W. Bratton, Jr., The "Nexus of Contracts" Corporation: A Critical Appraisal, 74 CORNELL L. REV. 407, 457-58, 464 (1989) (arguing that "[t]he nexus of contracts concept places the corporation on a foundation of contractual consent" and discussing the presence of "real adherents" to the "new economic theory" of the firm that is gaining legitimacy in legal discourse). For an example of a "real adherent," see STEPHEN M. Bainbridge, The New Corporate Governance IN Theory AND PRactice 30-31 (2008) (explaining Bainbridge's application of "The Hypothetical Bargain Methodology").

208. See generally Stewart, supra note 200. But see Joo, supra note 203, at 170 (arguing that "incorporating efficient-market assumptions, contractarianism makes two claims: that governance is consensual and that it is efficient").

209. See Thomas W. Joo, Contract, Property, and the Role of Metaphor in Corporations Law, 35 U.C. DAVIS L. REV. 779, 800 (2002) (arguing that the contractarian vision of contract is a laissez-faire one, which justifies the assumption that "economic relationships are the product of individual free will and rational deliberation, and the law respects them for this reason"). For an excellent example of an adherent to this theory, see BAINBRIDGE, supra note 207, at 30-31 (explaining Bainbridge's application of "The Hypothetical Bargain Methodology").

210. EASTERBROOK \& FTSCHEL, supra note 147, at 35-39. 
must remain permissive, rejecting mandatory legal rules as generally suboptimal. ${ }^{211}$

On closer inspection of corporate governance, this theory suggests that large, sophisticated investors play a central role in making corporate governance work within this legal market framework. ${ }^{212} 2_{\text {. In }}$ theory, professional investors and their consultants provide analysis of corporate management, governance structures, debt-equity ratios, and relative prowess when compared to competitors, ${ }^{213}$ which supplies the price mechanism with enough information for debt and equity markets to reward good corporate practice and punish poor performance. ${ }^{214}$ Thus, just as Easterbrook and Fischel suggested, what emerges is a corporate law that allows markets to function competently, encouraging "what is optimal for the firms and investors." 215

Within this aggregate contractarian theory, fair treatment of corporate constituents is rationalized as follows. If a corpörate constituent does not like the terms of a proposed contract with a corporation, it can negotiate for new terms, demand a higher price for contracting, or choose not to enter into a contract with the corporation in question. ${ }^{216}$ It is a consensual relationship. ${ }^{217}$ If a constituent (shareholder) is unhappy and markets are highly liquid, the constituent can "exit" the relationship. If enough shareholders exit, this will decrease share value and trigger a reason for management to prevent further exits, thereby policing managerial opportunism. 218

Furthermore, the cost of contracting will encourage corporate managers to make choices that balance the transaction costs of making a decision between all of the constituents affected. ${ }^{219}$ In this way, a contract enforces a balance of power between constituents, for although corporate managers have much of the ex ante authority, 220 the contractual ex post consequences discipline such discretionary behavior. ${ }^{221}$ For instance, efficient, rational incorporators will select

211. Joo, supra note 203, at 171.

212. See John C. Coffee, Jr., Liquidity Versus Control: The Institutional Investor as Corporate Monitor, 91 CoLUM. L. REV. 1277, 1291-93 (1991).

213. See EASTERBROOK \& FISCHEL, supra note 147, at 17-19, 23-24.

214. See id. at 19.

215. Id. at 7.

216. See BAINBRIDGE, supra note 207, at 30-31 (explaining Bainbridge's application of "The Hypothetical Bargain Methodology").

217. See Joo, supra note 203, at 163.

218. For the classic text, see AlBeRT O. HIRSChMAN, EXIT, VOICE, AND LOYALTY: RESPONSES TO DECLINE IN FIRMS, ORGANIZATIONS, AND STATES 21-29 (1970).

219. See EASTERBROOK \& FISCHEL, supra note 147, at 91-93, 217-18.

220. See, e.g., BAINBRIDGE, supra note 207, at 67-68.

221. See EASTERBROOK \& FISCHEL, supra note 147, at 91-93, 217-18. 
rules when incorporating that balance the transaction costs of deviating from the off-the-rack default rules of incorporation with the perceived benefit of doing so. ${ }^{222}$ Such freedom of rule selection allows the corporate form to have greater flexibility to respond to market demands and opportunities. 223

That said, some mandatory obligations are imposed on directors and management in an attempt to counter the inherent potential for power and/or information asymmetries between actors within corporate hierarchies. ${ }^{224}$ But generally. speaking, such mandatory rules are discouraged, since most are deemed to be unnecessary, and because the cost of electing to adopt choices that obviously disadvantage shareholders or creditors is so high that these choices become de facto mandatory; the market disciplines, while still leaving discretion for dynamic, entrepreneurial decisionmaking options. ${ }^{225}$

This aggregate contractarian perspective also discourages courts from attempting to compensate ex post facto for any ex ante errors in negotiating. If constituents of the corporation fail to negotiate for the risks involved in a particular contractual relationship, courts should just leave it to the market to police. ${ }^{226}$ Thus, from this perspective, the role of the courts ought to be as follows: "The courts may not rewrite [corporate contracts] under the guise of relieving one of the parties from the hardship of an improvident bargain. The Court cannot protect the parties from a bad bargain and it will not protect them from bad luck." 227 In this light, corporate law, and its judicial application, appears somewhat insensitive to the inequalities between contracting parties. It is hesitant to impose a stricter standard than freedom of contract, since doing so might inadvertently undermine market discipline and, therefore, the corporation as an economizing device. ${ }^{228}$

222. See Charles R.T. O'Kelley \& Robert B. Thompson, CoRporations aNd Other BUSINESS ASSOCIATIONS 8-20 (6th ed. 2010).

223. See EASTERBROOK \& FISCHEL, supra note 147, at 34-35.

224. For instance, a director may have a personal interest in the approval of a particular contract, and in such cases, strict procedural obligations are imposed upon that director. O'KeLley \& THOMPSON, supra note 222, at 277; see also Broz v. Cellular Info. Sys., Inc., 673 A.2d 148, 154-56 (Del. 1996).

225. See EASTERBROOK \& FiSCHEL, supra note 147, at 34-35.

226. See Concord Auto Auction, Inc. v. Rustin, 627 F. Supp. 1526, 1531-33 (D. Mass. 1986).

227. Id. at 1532-33 (internal citations omitted).

228. See EASTERBROOK \& FisCHEL, supra note 147, at 31-38. 


\section{E. Corporate Social Responsibility and Corporate Law}

In the classic corporate social responsibility of the Berle-Dodd debate of the $1930 \mathrm{~s}$, the issue was whether corporate power ought to be in the hands of shareholders as public interest representatives or managers as stewards of society. ${ }^{229}$ In the 1980 s and $1990 \mathrm{~s}$, the shift from corporate social responsibility (direct social obligation) to corporate responsibility (indirect social obligation through wealth creation) is captured by Easterbrook and Fischel's classic one master theory: if managers are only accountable to shareholders as investors, the market will force corporate responsibility (profitmaking). ${ }^{230}$ If managers are burdened by split loyalties, the door is open for managerial opportunism, and, accordingly, wealth production is compromised.231 Such interference, it was claimed, could easily jeopardize profits, which would have a net negative impact on all constituents within these organizations, because the capacity to generate wealth would be sacrificed in a blind attempt to achieve fairness. ${ }^{232}$ From this perspective, by producing wealth, managers are most responsible to society. ${ }^{233}$

As mentioned, Easterbrook and Fischel suggested that using regulations, other than corporate law, to cultivate markets that better deal with price uncertainties ${ }^{234}$ would be the best way to circumscribe corporate for-profit activities without undermining the corporation as an economizing device.235 For instance, if a regulator wants to prevent a corporation from releasing pollutants into a river, it should not change corporate function through reforming corporate law; rather, it should create a regulatory mechanism within the Environmental Protection Act for monitoring and fining potential river polluters. If the enforcement mechanism is sound, then no rational market actor will

229. See A. A. Berle, Jr., Corporate Powers as Powers in Trust, 44 HaRV. L. REv. 1049 (1931) Thereinafter Berle, Corporate Powers]; E. Merrick Dodd, Jr., For Whom Are Corporate Managers Trustees?, 45 HARV. L. REv. 1145 (1932); A. A. Berle, Jr., For Whom Corporate Managers are Trustees: A Note, 45 HARV. L. REV. 1365 (1932) [hereinafter Berle, A Note].

230. EASTERBROOK \& FISCHEL, supra note 147 , at 38 .

231. See id.

232. See id.

233. See id. at 35-38.

234. For an understanding of the relationship between the price mechanism and uncertainty, consider the case of "transfer pricing," which is an accounting term for the transfer of goods or services from one division or company (within the same group) to another in order to distribute revenue in a more efficient manner. See Joshua Ronen \& Kashi R. Balachandran, An Approach to Transfer Pricing Under Uncertainty, 26 J. AcCT. RES. 300, 301-02 (1988).

235. See, e.g., EASTERBROOK \& FISCHEL, supra note 147, at 37-39. 
attempt to violate this law because the potential risk grossly outweighs the potential profit. In other words, if regulators understand that corporate actors will violate the law if it is profitable to do so, then regulators can create the appropriate regulatory incentives to manipulate corporate behavior.

In this way, Easterbrook and Fischel reframed the corporate (social) responsibility debate in U.S. corporate legal scholarship. The corporate social responsibility of the Berle-Dodd debate shifted to a corporate responsibility debate in mainstream corporate legal scholarship. Shareholders were no longer characterized as proxies of the public interest, as Berle suggested, ${ }^{236}$ but as investors. ${ }^{237}$ Directors were no longer characterized as stewards of society, as Dodd suggested, ${ }^{238}$ but as champions of investors as a class. ${ }^{239}$ As a result, the corporation is understood as a tool, which best serves society when it solely focuses on profitmaking, creating the wealth necessary to allow other segments of society to cope with the world's problems.

\section{F. Conclusion}

As this section demonstrates, from the corporate legal perspective today, corporations are neither expected nor encouraged to be imbued with public spiritedness. They are profitmaking organizations that are encouraged to act in a self-interested manner. There are a number of interconnected assumptions that legitimate this perspective. First, the corporation can best serve society by being an efficient wealth creation device. ${ }^{240}$ Second, direct legal intervention in corporate governance undermines the efficiency of corporate wealth creation. ${ }^{241}$ Third, if managers serve one master-shareholders-then markets can police corporate managers and preserve the efficiency of corporate wealth

236. See Fenner L. Stewart, Berle's Conception of Shareholder Primacy: A Forgotten Perspective for Reconsideration During the Rise of Finance, 34 SEATTLE U. L. REV. 1457, 1458-59 (2011). But see Berle, Corporate Powers, supra note 229; Berle, A Note, supra note 229.

237. See id. But see, e.g., Lucian A. Bebchuk, Reply: Letting Shareholders Set the Rules, 119 HARV. L. REV. 1784 (2006) (arguing for increased shareholder power to change the rules of internal corporate governance); Lucian Arye Bebchuk, The Case for Increasing Shareholder Power, 118 HARV. L. REv. 833 (2005) (arguing that increasing shareholder power would improve corporate governance and enhance shareholder value).

238. See Dodd, supra note 229 , at 1153.54 .

239. See, e.g., Stephen M. Bainbridge, Director Primacy and Shareholder Disempowerment, 119 HARV. L. REv. 1735 (2006) (responding to Bebchuk's arguments for increased shareholder power over internal corporate governance).

240. See supra notes 230-27 and accompanying text.

241. See EASTERBROOK \& FISCHEL, supra note 147, at 38. 
creation. ${ }^{242}$ Fourth, corporate law must therefore enforce shareholder interests within corporate governance. ${ }^{243} \mathrm{Fifth}$, corporate law must then almost exclusively engage in agency issues between shareholders 'and management. ${ }^{244}$ Sixth, if regulators want to circumscribe the profitmaking function of corporations, then areas of law other than corporate law must be employed to change the price of doing business that corporations face. ${ }^{245}$ As a result, most corporate legal scholars view corporate law as legitimate when it serves as a conservative mechanism to avoid public interference and regulatory reform.

This conservative corporate law perspective is the dominant mindset of U.S. corporate legal culture. Although there are always dissenting opinions, this is the commonsense position in the business world. Regulators would face serious resistance if they attempted to experiment with corporate law in ways that might compromise the corporation as an economizing device. ${ }^{246}$

So, what about new governance's hope of "publicization of the private?" Its legitimacy has not been established. Moreover, it appears clear that publicization stands in the face of what is deemed to be the commonsense position within corporate governance thinking.

\section{The NARRATIVE OF ENTRENCHED PRIVATIZATION}

From a different perspective than what was outlined in the last section, this section reconnects to the idea of technocratic narratives, and suggests that governance narratives possess an additional quality that tends to discourage publicization. This quality is a lack of humanistic narratives, which can divorce decisionmaking from what is at stake, namely the violent consequences of that particular decision on a segment of society. ${ }^{247}$

To explain this quality, this article draws a distinction between two types of narratives: humanistic narratives and technocratic narratives. This article defines humanistic narratives as storylines with identifiable characters and a time sequence, which reveal the causes and consequences of characters' actions. Humanistic narratives grant the readers/isteners a digestible message that mirrors life experience. On the other side of the distinction are technocratic narratives, which this article defines as accounts used by technical experts and professionals

242. See supra notes 230-39 and accompanying text.

243. See Berle, A Note, supra note 229 , at 1365 .

244. See supra notes $230-35$ and accompanying text.

245. See supra notes $234-35$ and accompanying text.

246. See EASTERBROOK \& FISCHEL, supra note 147, at 35-39.

247. See Robert M. Cover, Violence and the Word, 95 YALE L.J. 1601, 1601 (1986). 
who seek to employ a spectrum of scientific methodologies, but most predominately economic ones, in an attempt to resolve governance issues.

Mae Kuykendall, in her article about the lack of strong narratives in corporate governance, chooses to label technocratic narratives as "disoourses" and humanistic narratives as just narratives. ${ }^{248}$ She argues that corporate law lacks the sort of narratives "that attract human interest," even though the corporation is a significant site of "human activity."249 Accordingly, although one might expect humanistic narratives, they are rarely present or employed within corporate governance. Kuykendall further notes that technocratic narratives in corporate governance generally rely on economic analysis of corporate interactions, which has the sanitizing effect of obscuring the social costs of particular choices. ${ }^{250}$ David Westbrook agrees, ${ }^{251}$ adding that such lack of humanistic narratives fails to provide corporate governance with heroes that inspire virtue. ${ }^{252}$

One can clearly appreciate that this lack of humanistic narratives is damaging to the hope of publicization. Yet, the situation may be even more alarming when one takes into account the effects of technocratic narratives on governance more broadly. For instance, Kerry Rittich suggests that the problems identified by corporate scholars, such as Kuykendall and Westbrook, might reach beyond corporate governance to impact public administrative agencies as well..$^{253}$

By the twentieth century, enlightened modern thinkers were painfully aware of the loss of normative certainty that accompanied accepting Nietzsche's thesis that the understanding of good was historically contingent. 254 Without normative certainty, decisionmakers grasped for the scientific method, which promised to reveal the "real issues at stake" by providing social facts on which sound regulatory frameworks could be constructed. ${ }^{255}$. This legitimated decisionmaking functions in a manner that mere power or politics could not. The

248. Mae Kuykendall, No Imagination: The Marginal Role of Narrative in Corporate Law, 55 BUFF. L. REV. 537, 541 (2007).

249. Id.

250. See id. at $547-48,589$.

251. See Mae Kuykendall \& David Westbrook, Introduction: Unsettling Questions, Disquieting Stories, 2009 MiCH. ST. L. REV. 817, 827-28.

252. See DAVID A. WeStBRoOK, City OF GOLD: AN APOlogy FOR Global CAPITALISM IN A TIME OF DisCONTENT 112 (2004).

253. See generally Rittich, supra note 77 .

254. See generally FrIEDRICH NIETZSCHE, BEYOND GOOD AND EvIL (R. J. Hollingdale trans., reprt. ed. 1990).

255. Rittich, supra note 253 , at 855. 
employment of social sciences by administrative agencies to solve social problems in this manner has been called functionalism.

Reflecting on the work of John Willis, Rittich argues that functionalism was successful in the New Deal era because it provided "a way to depoliticize the process of adjudication and diffuse the conflicts among the courts, the executive, and the legislature."256 During the interwar period in England, functionalists, such as Willis, defended the expansion of the modern administrative state, which was striving to meet the public's demands for greater state involvement in English society. ${ }^{257}$ As Martin Loughlin explains:

The functionalist style offered an alternative way of addressing the issues that were presenting themselves for resolution as matters of public law. It was therefore a practical, reformist approach, offering solutions to a variety of legal challenges facing modern government and spanning the range from institutional reforms to alternative modes of interpretation and methods of legal reasoning. This practical program of law reform was directly tied to the broader political movement encompassed under the broad heads of new liberalism, social democracy, progressivism, or democratic socialism. ${ }^{258}$

The British functionalist movement paralleled that of American Legal Realists, embracing governance by teams of experts, who could use their mastery of science to determine what was best for society. ${ }^{259}$

John Dewey rejected this expert paternalism, which subsequently made his ideas unfashionable at the time, but he pressed on, insisting that if a "government by experts" did not earnestly consult citizens, then such government could amount to no more than "an oligarchy managed in the interests of the few." ${ }^{60} \mathrm{He}$ insisted, "the enlightenment must proceed in ways which force the administrative specialists to take

256. Id.

257. See Peter L. Lindseth, Reconciling with the Past: John Willis and the Question of Judicial Review in Inter-War and Post-War England, 55 U. TononTo L.J. 657, 658 (2005).

258. Martin Loughlin, The Functionalist Style in Public Law, 55 U. ToRONTO L.J. 361, 362-63 (2005).

259. See generally Robert W. Gordon, Willis's American Counterparts: The Legal Realists' Defence of Administration, 55 U. TORONTO L.J. 405 (2005) (identifying commonalities between American and British Legal Realists).

260. 2 John Dewey, The Public and Its Problems, in The LATER WoRKs, 1925-1953, at 235, 365 (Jo Ann Boydston ed., 1984). 
account of the needs [of the masses]."261 But progressives, such as Willis, believed such administrative expertise could determine what was best for citizens, legitimating their authority in the modern world by paving the path to progress with their technical knowledge.

Today, the technocratic mindset of functionalism remains the same; however, as Rittich suggests, its use has changed, supporting the conservative interests it once rivaled. ${ }^{262}$ Rittich argues that regulators now measure the performance of their institutions "by the extent to which they further efficient transactions and encourage private-sector activity." 263 She continues, "these objectives, in turn, are typically understood to involve creating the legal infrastructure that furthers the interests of investors and capital holders through, inter alia, enhanced protection for property and contract rights." 264 Rittich describes an emerging power structure for governance in which "[c]adres of technocrats and professionals ... set the terms and conditions under which states, markets, civil society groups, and individuals interact."265 This has led some to agree, in retrospect, that Dewey's rejection of expert paternalism ${ }^{266}$ may have deserved greater credence at the time.

The dangers of technocratic narratives have been clearly echoed by other scholars. On the more radical end of the spectrum is David Harvey. Harvey regards this problem of technocratic narratives as reaching far beyond legal discourse. He views such narratives as part of a conscious campaign over communication to create a "hegemonic discourse," which is propagated through mass media-in particular, the entertainment industry. 267 In Harvey's opinion, this hegemonic discourse has already corrupted "ways of thought and political-economic practices to the point where it is now part of the commonsense way we interpret, live in, and understand the world." 268 Thus, from his Marxian perspective, such narratives are powerful examples of how capitalists have adapted and reasserted their ideology so as to once again lure the proletariat into undermining their own interests. Harvey believes this to be one of the central achievements of the neoliberal movement. 269

Like Harvey, Rittich suggests that ideology is corrupting governance, using a scientific and technical language that appears

261. Id.

262. See Rittich, supra note 253 , at 855.

263. Id.

264. Id.

265. Id. at 856 .

266. DEWEY, supra note 260 , at 365.

267. David Harvey, Neoliberalism as Creative Destruction, 610 ANnals AM. ACAD. POL. \& Soc. SCI. 22, 22-23, 34 (2007).

268. Id. at 22 .

269. See id. 
depoliticized but, in fact, limits choices within the "regulatory calculus" to those that embrace "efficiency, expertise, and cost-containment." 270 In this way, humanistic narratives are regarded as unsuitable and are thus marginalized within decisionmaking. Rittich's argument demonstrates how technocratic narratives depoliticize and dehumanize social conflicts by divorcing them from the personal and necessarily political humanistic narratives in the name of the scientific method. What is dangerous about this dehumanization of narratives is that social conflicts can be abstractified, practically concealing the connection between particular choices and the violent consequences of that particular course of action on a segment of society. Thomas Nagel brings home this last point when he writes: "Once the door is opened to calculations of utility ... the usual speculations . . . can be brought to bear to ease the consciences of those responsible for a certain number of charred babies."271

What the positions of Kuykendall, Harvey, and Rittich all have in common is the lament over the underlying ideology that has presently captured technocratic narratives. They each highlight, in different ways, how technocratic narratives guide their users to prioritize economic needs over social needs when it is necessary to choose between the two. As Harvey pointed out, the normative message that economic needs must always be the priority over all others presents itself as commonsense, radicalizing any suggestion to the contrary. ${ }^{272}$

Kuykendall's approach inspires meaningful discourse between ideological adversaries, since it allows for a critical reflection on particular communication without heightening the distinction between such adversaries. One can imagine that approaching such a discourse like an embattled proletariat would probably prove to be less than successful. Kuykendall approaches sensitive issues with tact, so as not to alienate a corporate legal audience, which usually tends to be conservative. Consider Kuykendall's diplomacy in the following passage:

The absence of [humanistic] narrative from corporate law is substantially explained by the nature of the undertaking of producing wealth and by the social formation of business. The absence of [such] narrative is not a nefarious scheme to undermine critique, although it tends to have that effect. Rather, the underlying

270. Rittich, supra note 253 , at 867 .

271. THOMAS NAGEL, MORTAL QUESTIONS 59 (1979).

272. See Harvey, supra note 267 , at 22-23. 
project of generating wealth does not produce rich human stories. ${ }^{273}$

Kuykendall's approach does not point fingers at capitalists and the cadres of technocrats whom Harvey would suggest are operating behind the scenes to control societies. As a result, the chance of constructive bipartisan debate, as well as the potential emancipation from a particular mindset, becomes more likely, since criticism can be deftly directed at a normative level rather than a more personal one. In fact, her article sparked broad debate in the corporate legal community, resulting in a symposium at Michigan State University College of Law entitled the Business Law and Narrative Symposium. ${ }^{274}$

In conclusion, the problem of a lack of humanistic narrative appears not to be isolated to private governance (corporate governance), but also appears to seriously threaten public governance (administrative agencies) as well. Again, publicization suggests that there will be the "percolation" of values from public governance to private governance. ${ }^{275}$ So, if this percolation process transports values from public to private, what happens when there needs to be a publicization of the public as well? In other words, what if privatization has been so invasive within governance that public governance no longer imbues Braithwaite's "public law values"? Or, what if it never did? The above account suggests that this might be the case. And if this is the case, then the project of new governance might be even more dangerously optimistic than this article suggests.

\section{CONCLUSION}

This article has attempted to dash the hopes of those who quell their fear of privatization with the faith that the clouds shall part and corporate doves imbued with the twin virtues of benevolent kindness and efficiency shall save us all from the woes of modern governance. Based on the literatures reviewed, there is little merit in hoping that this will occur. The blurring of public and private in governance today will not lead to the publicization of corporations in some spontaneous way-to think otherwise amounts to magical thinking.

That said, magical thinking has an important role in the cultivation of ideology. Those that champion privatization have the "foundation

273. Kuykendall, supra note 248 , at 555.

274. Press Release, Mich. State Univ. Coll. of Law, Michigan State Law Review to Host Business Law and Narrative Symposium (Sept. 10, 2009), available at http://www.law.msu.edu/news/2009/releases/business-narrative.html.

275. Braithwaite, supra note 7 , at 4. 
myth" of the medieval lex mercatoria ${ }^{276}$ - the promise of a pure free market that can shepherd a commoditized humanity through the wonders of the price mechanism. ${ }^{277}$ If this is so, then does the myth of publicization create an appropriate counterview of social order, adequately challenging the vision of a pure free market and legitimating opposition to it? A better myth is possible.

There needs to be more emphasis on social justice, ${ }^{278}$ equality, ${ }^{279}$ and the socioeconomic impacts of privatization. ${ }^{280}$ Maybe there needs to be a louder campaign that stresses an understanding of privatization through the lens of human rights, ${ }^{281}$ which asserts that international customary law obliges ${ }^{282}$ governments to ensure that each of their

276. For more on how such "foundation myths" function, see Nicholas H.D. Foster, Foundation Myth as Legal Formant: The Medieval Law Merchant and the New Lex Mercatoria, FORUM HISTORIAE JURIS (Mar. 18, 2005), http://www.forhistiur.de/ zitat/0503foster.htm. See also Michaels, supra note 163, at 264-65, 267.

277. See, e.g., Hayek, supra note 16, at 528 (arguing that a planned economy could never match the efficiency of the free market).

278. See, e.g., Demetrius S. Iatridis, The Social Justice and Equality Contexts of Privatization, in Social JUSTice and The Welfare State in Central and Eastern EUROPE: THE IMPACT OF PRIVATIZATION 3 (Demetrius S. Iatridis ed., 2000) (describing the negative social impacts of privatization in Central and Eastern European countries).

279. See, e.g., id. at 18.

280. See, e.g., Danwood Mzikenge Chirwa, Water Privatisation and Socio-Economic Rights in South Africa, 8 LAW DEMOCRACY \& DEV. 181 (2004).

281. See, e.g., Capitalist Punishment: Prison Privatization \& Human Rights (Andrew Coyle et al. eds., 2003); WILLIAM F. FELICE, THE GLOBAL NEW DEAL: ECONOMIC AND SOCIAL HUMAN RIGHTS IN WORLD Politics (2003); Alfred C. Aman, Jr., Privatization, Prisons, Democracy, and Human Rights: The Need to Extend the Province of Administrative Law, 12 IND. J. GLOBAL LEGAL STUD. 511 (2005); Alana Klein, Judging as Nudging: New Governance Approaches for the Enforcement of Constitutional Social and Economic Rights, 39 CoLUM. HUM. RTS. L. REv. 351 (2008); Laurence J. Kotlikoff et al., Privatizing Social Security in the United States-Comparing the Options, 2 REv. EcoN. DYNAMICS 532 (1999).

282. Although some argue that the Universal Declaration of Human Rights "is not binding," they argue that "most of its rights have been incorporated into the domestic legal systems of most countries[,] . . . especially . . . the rights in the Declaration's first 'column' [namely civil and political rights]." Mary Ann Glendon, The Rule of Law in the Universal Declaration of Human Rights, 2 Nw. J. INT'L HUM. RTS. 1, 5 (2004). Hannum takes the broader view that, in principle, the Universal Declaration of Human Rights may be invoked as a source of customary international law and is, in its entirety, binding (again stressing in principle). See generally Hurst Hannum, The Status of the Universal Declaration of Human Rights in National and International Law, 25 GA. J. INT'L \& COMP. L. 287 (1995). In accordance with Hannum's view, it can be argued that there is a legal and moral obligation on all nations to enforce not only civil and political rights, but also social and economic rights. For more on the differences, compare the International Covenant on Civil and Political Rights, G.A. Res. 2200A (XXI), UN Doc. A/6316, 999 U.N.T.S. 171, 6 I.L.M. 368 (Dec. 16, 1966), with the International Covenant on Economic, 
citizens has the right to dignity, an adequate standard of living, housing, social services, and education. ${ }^{283}$ Maybe there also needs to be further declarations that these rights are binding on all nations ${ }^{284}$ and, thus, are "not negotiable"!285 Of course, this is only one of many options, which could coordinate and galvanize the fragmentation of social reaction that Polanyi predicted in his theory of the double movement. ${ }^{286}$

That said, human rights framing may also be inadequate. In the face of how countries observe human rights, ${ }^{287}$ the hope that states will meet these human rights obligations (in particular social, cultural, and economic rights) ${ }^{288}$ is probably as close to becoming reality as a reincarnation of the medieval lex mercatoria. ${ }^{289}$ Yet, this human rights framing of the privatization issue provides a stronger "foundation myth" than publicization and a better counter to the present spin of the freemarketeers. Either way, there is more work to be done in Nietzsche's Dark Workshop.

Social and Cultural Rights, G.A. Res. 2200A (XXI), U.N. Doc. A/6316; 993 U.N.T.S. 3; 6 I.L.M. 368 (Dec. 16, 1966).

283. Universal Declaration of Human Rights, G.A. Res. 217A (III), U.N. Doc. A/810 at 71, arts. 22, 25-26 (Dec. 10, 1948).

284. See Hannum, supra note 282, at $289,319,323-25$, 330-34 (providing examples of various theorists' and government officials' statements on whether international human rights standards are binding).

285. Titus Edjua \& Antony Crockett, Human Rights Not Negotiable, 28 InT'L FIN. L. REV. 50, 50-51 (2009); ANDREA SHEMBERG, STABILIZATION CladusES AND HUMAN RIGHTS 10 (2009), available at http://www.ifc.org/wps/wcm/connect/9feb5b00488555eab8c4fa6a6515bb18/ Stabilization\%2BPaper.pdf?MOD=AJPERES\&CACHEID=9feb5b00488555eab8c4fa6a651 $5 \mathrm{bb} 18$; Irina Bokova, Message from the Director-General of UNESCO, UNITED NATIONS (Dec. 10, 2011), http://www.un.org/en/events/humanrightsday/2011/unesco.shtml ("Whatever the circumstances or complexity of the challenges that we face, the observance of human rights is not negotiable.").

286. POLANY, supra note 35 , at $79,136$.

287. To better appreciate human rights conditions on a country-by-country basis, see Human Rights Watch's Regional Reports. Regions, HUM. RTS. WATCH, http://www.hrw.org/regions (last visited Apr. 3, 2014).

288. See International Covenant on Civil and Political Rights, supra note 282; International Covenant on Economic, Social and Cultural Rights, supra note 282.

289. See, e.g., Emily Kadens, The Myth of the Customary Law Merchant, 90 TEX. L. REv. $1153,1159-60,1181-96,1205-06$ (2012) (questioning the validity of claims concerning the existence of custom in the form of lex mercatoria). 
